\title{
Lurasidone - pharmacodynamic and pharmacokinetic properties, clinical potential and interaction risk
}

\author{
Lurasidon - właściwości farmakodynamiczne i farmakokinetyczne, potencjat \\ kliniczny i ryzyko interakcji
}

Marcin Siwek ${ }^{1}$, Anna J. Krupa ${ }^{2}$, Anna Wasik ${ }^{1}$

\section{ABSTRACT}

Lurasidone is a novel second-generation antipsychotic approved for the treatment of schizophrenia and bipolar depression in adults. It displays high affinity for D2

Received: 13.05 .2020
Accepted: 13.06 .2020

CORRESPONDENCE ADDRESS / ADRES DO KORESPONDENCJI Dr hab. n. med. Marcin Siwek

Katedra Psychiatrii UJCM, Zakład Zaburzeń Afektywnych ul. M. Kopernika 21 A, 31-501 Kraków

email:drmarcinsiwek@gmail.com and 5-HT2A and 5-HT7 receptors, moderate affinity for 5-HT1A and a2C-noradrenergic receptors, and negligible affinity for histamine $\mathrm{H} 1$ and muscarinic $\mathrm{M} 1$ receptors. It acts as potent D2, 5-HT2A and 5-HT7 antagonist and partial 5-HT1A agonist. Lurasidone taken orally is rapidly absorbed with the time to maximum concentration of 1-3 hours. Lurasidone should be taken with food (at least 350 $\mathrm{kcal}$ ) due to limited absorption. The mean elimination half-life of lurasidone is 18.1-25.5 hours for doses 20-80 $\mathrm{mg} /$ day and 28.8-37.4 hours for doses of 120-160 mg/day. Steady-state is reached within 7 days. The drug is metabolised via CYP3A4 and excreted mainly in faeces (67-80\%) and with urine (about 8-19\%). The use of lurasidone with strong inhibitors or inducers of CYP3A4 (e.g. ketoconazole, erythromycin, or carbamazepine, respectively) is contraindicated. In the case of combined treatment of lurasidone and moderate inhibitors of CYP3A4, the dose of lurasidone should be decreased to $40 \mathrm{mg} /$ day. Lurasidone is an inhibitor of P-glycoprotein and could increase the level of digoxin and potentate the side effects risk of this drug. Pomelo, grapefruit, or a large amount of oranges should be avoided in the diet during treatment with lurasidone. Pharmacodynamic properties of lurasidone underlie its antipsychotic, antidepressant, precognitive, and sleep-awake rhythm normalising activity.

\section{STRESZCZENIE}

Lurasidon to nowy lek przeciwpsychotyczny II generacji zarejestrowany w leczeniu schizofrenii i epizodów 
depresyjnych w przebiegu choroby afektywnej dwubiegunowej u dorosłych. Lek posiada wysokie powinowactwo względem receptorów D2 i 5-HT2A, 5-HT7, umiarkowane wobec receptorów 5-HT1A i a2C-adrenergicznych oraz nieznaczące wobec receptorów H1 i M1. Lurasidon podany doustnie jest szybko wchłaniany, po 1,5-3 godzinach osiąga maksymalne stężenie. Ze względu na niską absorbcję lek powinien być przyjmowany z posiłkiem (co najmniej $350 \mathrm{kcal}$ ). Okres półtrwania dla dawek 20-80 mg na dobę wynosi 18,1-25,5 godziny, dla dawek 120-160 mg na dobę 28,8-37,4 godziny. Stężenie stacjonarne jest osiągane w ciągu $7 \mathrm{dni}$. Lek jest metabolizowany przy udziale izoenzymów CYP3A4 i wydalany głownie z kałem (67-80\%), w mniejszym stopniu z moczem (8-19\%). Przeciwwskazane jest jednoczesne stosowanie lurasidonu z silnymi inhibitorami lub induktorami CYP3A4 (np. ketokonazolem, erytromycyną czy karbamazepiną, odpowiednio). Podanie z umiarkowanymi inhibitorami CYP3A4 wymaga zmniejszenia dawki leku do $40 \mathrm{mg}$ na dzień. Lurasidon jest inhibitorem glikoprotein P, w związku z czym może zwiększać stężenie digoksyny i ryzyko wywoływanych przez nią działań niepożądanych. Podczas przyjmowania lurasidonu należy unikać spożywania pomelo, grejpfrutów i dużych ilości pomarańczy. $Z$ właściwości farmakodynamicznych lurasidonu wynika jego aktywność przeciwpsychotyczna, przeciwdepresyjna, prokognitywna, jak również normalizująca rytm snu i czuwania.

\section{Introduction}

There are various antipsychotics available today for the treatment of schizophrenia and the bipolar disorder. However, despite many years of continued studies and a high diversity of antipsychotics, in many patients it is difficult to achieve satisfactory treatment results. To a great extent, this results from insufficient efficacy of antipsychotics in terms of the reduction of positive and negative symptoms, cognitive dysfunctions or depressive symptoms. Furthermore, the currently applied antipsychotics are often characterised by an adverse-effects profile which results in a patient's discontinuation of the therapy or impedes the achievement of functional remission (Gorostowicz et al., 2020). Therefore, there are ongoing studies on the synthesis and evaluation of novel, more effective and safe antipsychotics (Carpenter and Davis, 2012). Lurasidone is one of the relatively recently introduced antipsychotics. The aim of this study is a concise discussion of the pharmacodynamic and pharmacokinetic properties of lurasidone as well as the potential interactions related to its use.

\section{Structure and pharmacodynamics of lurasidone}

Lurasidone is an atypical antipsychotic which belongs to piperazine derivatives, similarly to aripiprazole and ziprasidone (Fig. 1).

Lurasidone action profile on receptors is presented in Fig. 2. Table 1 compares the lurasidone receptor profile with chosen novel and commonly used antipsychotics.

Lurasidone is a strong antagonist of D2 receptors and its affinity for this receptor is approximately 3 -fold higher that for haloperidol and even 20-fold higher than for olanzapine. In the positron emission tomography (PET), D2 receptors occupancy was evaluated. Wong et al. (2013)

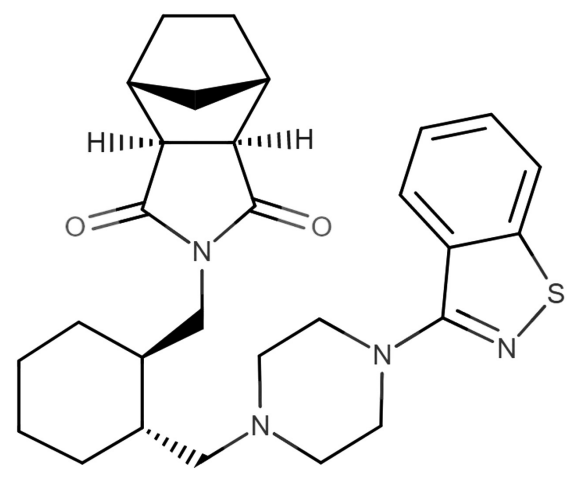

Figure 1. The structure of lurasidone (Wishart et al., 2018)

studied healthy male subjects to whom lurasidone was administered in a singular dose of $10-80 \mathrm{mg}$. The PET results showed that the level of D2 receptors occupancy was similar in the following regions: ventral striatum, putamen and caudate nucleus and equalled, depending on the administered dose: $10 \mathrm{mg}-41-43 \%, 20 \mathrm{mg}-51-$ $55 \%, 40 \mathrm{mg}-63-67 \%, 60 \mathrm{mg}-77-84 \%, 80 \mathrm{mg}-73-79 \%$. Among the studied subjects, who were administered with the doses of 10-60 mg of the medication, there was a relationship between the D2 receptor occupancy with lurasidone and its concentration, as well as its major metabolite in serum (Wong et al., 2013). Similarly, Potkin et al. (2014) conducted a study which incorporated the PET imaging. The study included schizophrenia or schizoaffective disorder patients. Participants were administered with lurasidone in the doses of 80,120 or $160 \mathrm{mg} /$ day. The results showed a significant correlation between the D2 receptor occupancy in subcortical structures and the serum lurasidone concentration; the effect was highest in the globus pallidus, slightly lower in caudate nucleus, putamen, thalamus and amygdala, and the lowest in nucleus accumbens. As described by 
Table 1. Pharmacodynamics of lurasidone and chosen APDs (Solmi et al., 2017; Das et al., 2016; Roth et al., 2004; Frankel and Schwartz, 2017; Citrome, 2015; Andressen et al., 2015; Tyler et al., 2017; Olten and Bloch, 2018)

\begin{tabular}{|c|c|c|c|c|c|c|c|}
\hline \multirow[t]{2}{*}{ Receptor } & \multicolumn{7}{|l|}{ Antipsychotics } \\
\hline & Lurasidone & Brexpiprazole & Cariprazine & Aripiprazole & Risperidone & Olanzapine & Haloperidol \\
\hline D2 & $++++(-)$ & $++++(+/-)$ & $++++(+/-)$ & $++++(+/-)$ & $+++(-)$ & $++(-)$ & $+++(-)$ \\
\hline D3 & $++(-)$ & $+++(+/-)$ & $++++(+/-)$ & $++++(+/-)$ & ++ & $+++\backslash++(-)$ & $+++\backslash++(--)$ \\
\hline 5-HT1A & $+++(+/-)$ & $++++(+/-)$ & $+++(+/-)$ & $+++(+/-)$ & $+(-)$ & + (inhibition?) & - \\
\hline 5-HT2A & $++++(-)$ & $++++(-)$ & $+++(-)$ & $+++(-)$ & $++++(-)$ & $+++(-)$ & $++(-)$ \\
\hline 5-HT2B & $?$ & $+++(-)$ & $++++(-)$ & $++++(--)$ & $++/+(-)$ & $?$ & $?$ \\
\hline 5-HT2C & $+(-)$ & $++(-)$ & $+(-)$ & $++(+/-)$ & $++(-)$ & $++(-)$ & - \\
\hline 5-HT7 & $++++(-)$ & $+++(-)$ & $+(-)$ & $++(+/-)$ & $++++/+++(-)$ & $++/+(--)$ & $++/+$ \\
\hline a1 & $++(-)$ & $++++/+++(-)$ & $++(-)$ & $++(-)$ & $+++(-)$ & $++(-)$ & $++(-)$ \\
\hline$a 2 A$ & $++(-)$ & $++(-)$ & $?$ & $++(-)$ & $+++(-)$ & $+(-)$ & + \\
\hline $\mathrm{H} 1$ & $-(-)$ & $++(-)$ & $++(-)$ & $++(-)$ & $+++(-)$ & $++++(-)$ & + \\
\hline M2 & $-(-)$ & $-(-)$ & $-(-)$ & $-(-)$ & $-(-)$ & $+(-)$ & - \\
\hline M3 & $-(-)$ & $?$ & $?$ & $-(-)$ & $-(-)$ & $+(-)$ & $-(-)$ \\
\hline \multicolumn{8}{|c|}{$\begin{array}{l}++++-\mathrm{Ki}<1-\text { very strong affinity, }+++-1<\mathrm{Ki}<10-\text { strong affinity, }++-\mathrm{Ki} 10<\mathrm{Ki}<100-\text { moderate affinity, }+100<\mathrm{Ki}<1000-\text { weak } \\
\text { affinity, }-1000<\mathrm{Ki}-\text { minimal affinity, ? - no data, }(-)-\text { antagonism towards a chosen receptor, (+/-) partial agonism towards a chosen } \\
\text { receptor, (--) - inverse agonism towards a chosen receptor }\end{array}$} \\
\hline
\end{tabular}

Nordstrom et al. (1993), Farde et al. (1995) or Mamo et al. (2004), the antipsychotic action of neuroleptics can be observed when approximately $65 \%$ of the $\mathrm{D} 2$ receptor occupancy is achieved in subcortical areas. Potkin's et al. (2014) calculations revealed that to achieve such D2 receptor occupancy, serum lurasidone concentration (together with its major metabolite ID-14283) should be higher than $70 \mathrm{ng} / \mathrm{ml}$. Furthermore, after a week of lurasidone therapy, there was a significant correlation between the $\mathrm{D} 2$ receptor occupancy in subcortical areas and the improvement in positive symptoms (Potkin et al., 2014). Fig. 3 shows a diagram presenting a relationship between dopaminergic neurotransmission abnormalities and symptoms experienced by schizophrenia patients.
For patients experiencing positive symptoms, both in the course of schizophrenia and mania, the dopaminergic transmission level in the mesolimbic pathways is increased. By blocking the $\mathrm{D} 2$ receptors, lurasidone (similarly to the majority of other atypical antipsychotics with proved efficacy) allows to reduce the dopamine-dependant neurotransmission, hence its action in reducing positive symptoms can be observed. Among patients who experience negative symptoms and cognitive dysfunctions in the course of schizophrenia and such symptoms of depression as anhedonia, psychomotor retardation, social withdrawal, decreased motivation and impaired executive functions, a reduction in the dopamine transmission in the mesocortical pathways can be observed.
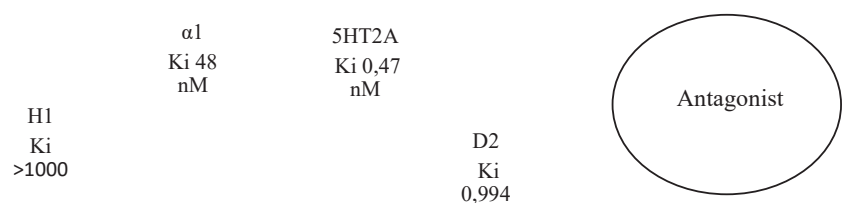

$$
\begin{gathered}
5 \mathrm{HT} 7 \\
\mathrm{Ki} \\
0,495
\end{gathered}
$$$$
\begin{gathered}
\mathrm{D} 3 \\
\mathrm{Ki} 15,7 \\
\mathrm{nM}
\end{gathered}
$$

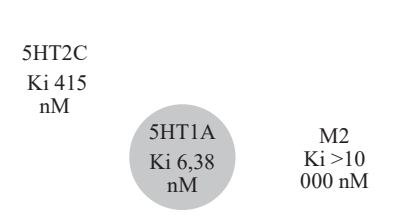

$\alpha 2$ $\mathrm{Ki} 10-$
$40 \mathrm{nM}$

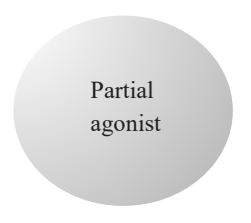

Figure 2. The affinity and intrinsic activity of lurasidone toward monamin and muscarinic receptors 

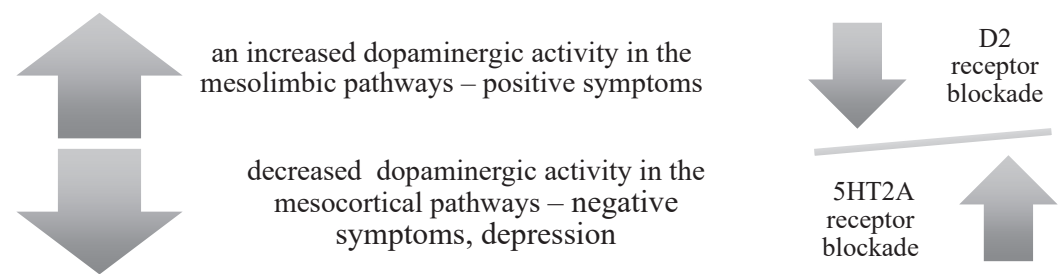

Figure 3. The relationship between dopaminergic activity and clinical symptoms. The influence of lurasidone on dopaminergic pathway

By inhibiting the serotonin $5 \mathrm{HT} 2 \mathrm{~A}$ receptors, lurasidone (like other atypical antipsychotics) promotes mesocortical dopaminergic transmission and, as a result, reduces the abovementioned negative symptoms of schizophrenia and depression. The inhibition of the 5HT2A receptors also affects the dopaminergic transmission in other pathways based on dopamine signalling: (1) nigrostriatal, whose inhibition is connected with the development of extrapyramidal symptoms; and (2) tuberoinfundibular, whose dopamine activity reduction is linked to the risk of hyperprolactinemia. Dopamine transmission inhibition due to the D2 receptor blockade is therefore partially neutralised due to the $5 \mathrm{HT} 2 \mathrm{~A}$ receptors inhibition which increases dopaminergic transmission. As a result, lurasidone therapy is characterised by a relatively low risk (as compared to e.g. risperidone or haloperidol which are included in the Table) of the development of such adverse effects as extrapyramidal symptoms or hyperprolactinemia. However, the risk is higher than for e.g. quetiapine, olanzapine or clozapine (Greenberg and Citrome, 2016; Solmi et al., 2017; Mamo et al., 2004).

Lurasidone, apart from the above-mentioned pharmacodynamic properties, is a partial agonist of the 5HT1A receptors. There are 2 known types of 5HT1A receptors: autoreceptors located in the presynaptic membrane of neurons coming from the dorsal raphe nuclei (DRN), where their activation is connected with a reduction of serotonin transmission and heteroreceptors of postsynaptic membranes of glutamatergic and GABAergic neurons of the limbic system and medial prefrontal cortex (mPFC). Partially agonistic action of lurasidone on the 5HT1A autoreceptors in DRN is linked with their consecutive desensitisation/downregulation and facilitation of serotonin transmission, which constitutes one of the main mechanisms of development of the anti-depression effect. In a slightly different mechanism, by serotonin increase in the synaptic cleft, the 5HT1A receptor downregulation takes place also as a result of the therapy with selective serotonin/serotonin and noradrenaline reuptake inhibitors. On the other hand, the effect of lurasidone on 5HT1A heteroreceptors in the postsynaptic membranes of glutamatergic and GABAergic cells in the limbic system and $\mathrm{mPFC}$ may partially be responsible for the procognitive as well as antipsychotic effects (Okada et al., 2019a). Takekita et al. (2015) published a meta-analysis of the studies which utilised the GWAS method (Genome Wide Association Studies) which underlines the significance of polymorphism of the 5HT1A receptor gene for the response to antipsychotic therapy in acute schizophrenia. Yoshikawa et al. (2019) conducted a meta-analysis of three studies in which the efficacy of lurasidone therapy in schizophrenia was verified (together with other two efficacy-evaluating antipsychotics in this indication), also based on the GWAS method. The results of their study confirm a significant interdependence between the 5HT1A polymorphism and the reduction of the Positive and Negative Syndrome Scale scores in the European population, but not in the African population (Yoshikawa et al., 2019).

Lurasidone is a strong antagonist of the $5 \mathrm{HT} 7$ receptors, which constitutes one of the major mechanisms underlying its mood-improving action and leading to cognitive function improvement (similarly to vortioxetine) (Greenberg and Citrome, 2016). The activity of serotoninergic and GABAergic neurons in DRN is limited, first and foremost by the 5HT1A receptors, while stimulation of GABAergic transmission depends mainly on agonism of 5HT7 receptors (Fig. 4). Lurasidone mechanism of action in these areas was studied in details by Okada et al. (2019a). They conducted a study on rats which were administered with lurasidone and other molecules that modify the action of serotonin receptors or NMDA. Then, the authors evaluated the serotoninergic transmission in DRN, MDTN (mediodorsal thalamic nucleus) and in mPFC as well as GABA-related transmission in DRN using the chromatography method. They observed that administration of SB269970 (5HT7 antagonist) or lurasidone (also used systemically) in the DRN area leads to GABAergic disinhibition, but is not connected with the increase of serotoninergic transmission in DRN, MDTN or MPFC. However, administration of the NMDA receptor inhibiting agent (MK-801) in the DRN area led to a significant intensification of serotonin release by a reduction of the inhibiting activity of GABAergic neurons. On the other hand, a simultaneous administration of lurasidone with a 5HT1A receptor blocking agent (WAY100635) led to a dose-dependent increase of serotonin transmission, which suggests that a partial agonism of receptors of 5HT1A autoreceptors prevents from serotoninergic hyperactivation. These results indicate that to promote serotoninergic transmission with lurasidone, its 
The regulation of 5-HT neurotransmission in DRN

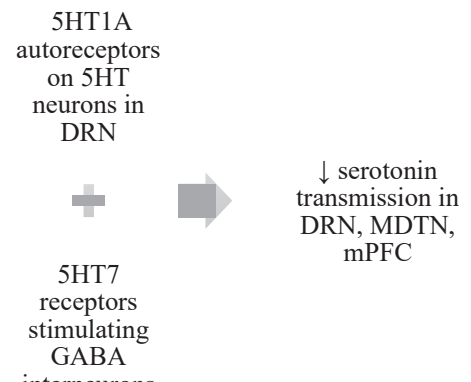

The influence of lurasidone on the serotonergic neurotransmission

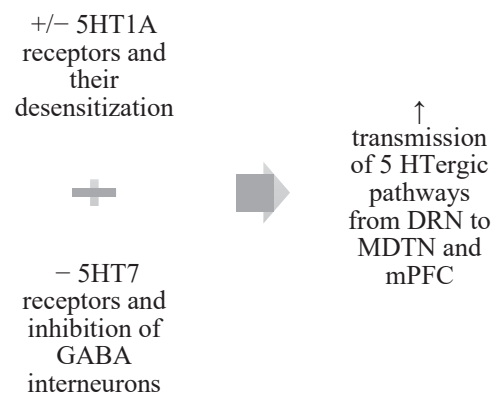

(+/-) - partial agonism, (-) - antagonism, $\uparrow$ - increment, $\downarrow$ - decrement, 5HT - serotonin, DRN - dorsal raphe nucleus, MDTN - mediodorsal thalamic nucleus, mPFC - medial prefrontal cortex

Figure 4. The impact of lurasidone on the regulating mechanisms of 5-HT neurotransmission

simultaneous action on 5HT1A and 5 HT7 receptors is necessary, which leads to their desensitisation, and in effect the reduction in serotonin-dependent transmission inhibition and promotion of the glutamatergic transmission in the limbic system and mPFC (Okada et al., 2019a).

5HT7 receptor inhibition is linked with lurasidone efficacy in the area of negative and positive symptoms. In the pathophysiology of schizophrenia, some role yet still not fully understood - is played by the glutamatergic neurotransmission. In the $20^{\text {th }}$ century, it was observed that the utilisation of the NMDA receptor antagonists (N-methyl-D-aspartate receptor), glutamate receptor selectively activated by the $\mathrm{N}$-methyl-D-aspartate acid (NMDA), phencyclidine and ketamine, led in healthy individuals to the development of both positive and negative symptoms of schizophrenia (Malhotra et al., 1996). Scientific data derived from in vitro and animal studies indicate that lurasidone, by its antagonistic action on the 5 HT7 receptors, in an indirect way modulates glutamatergic transmission (Okada et al., 2019b). Thalamus, which sends glutamatergic projections to the insula and prefrontal cortex, is a structure in which 5HT7 receptors are highly represented (Hedlund and Sutcliffe, 2004; Gogolla, 2017). On the other hand, insula has numerous functional connections with subcortical and cortical structures which control perception of sensory stimuli, emotions, motivation or cognitive functioning. Neurotransmission dysfunctions in insula are connected both to positive and negative symptoms of schizophrenia (Tian et al., 2019; Wylie, Tregellas, 2010). Okada et al. conducted a study on rats in which they evaluated transmission in MDTN and insula after administrating MK801 (NMDA antagonist) or lurasidone to rats in the area of one or both of these structures. The results suggest that lurasidone has a modulating effect on glutamatergic transmission in an indirect way, i.e. by the inhibition of the 5HT7 receptors located in the thalamus (Okada et al., 2019b). Available data also indicates that the modulating effect of lurasidone on glutamatergic transmission, apart from 5HT7 inhibition, is also dependent on 5HT1A partial agonism (Huang et al., 2018).

To conclude, the results of the above-mentioned studies show that the 5 HT7 receptor blockade by the glutamatergic transmission modulation limits the activity of dopaminergic and noradrenergic neurotransmission in mesolimbic pathways and promotes catecholaminergic signalling in mezocortical pathways (Fig. 5). Additionally, on the basis of the conducted animal trials, it can be concluded that this effect depends on partial agonism of lurasidone to 5HT1A receptors.

Procognitive action of lurasidone (Harvey et al., 2013; Harvey et al., 2015; Harvey et al., 2016), apart from its

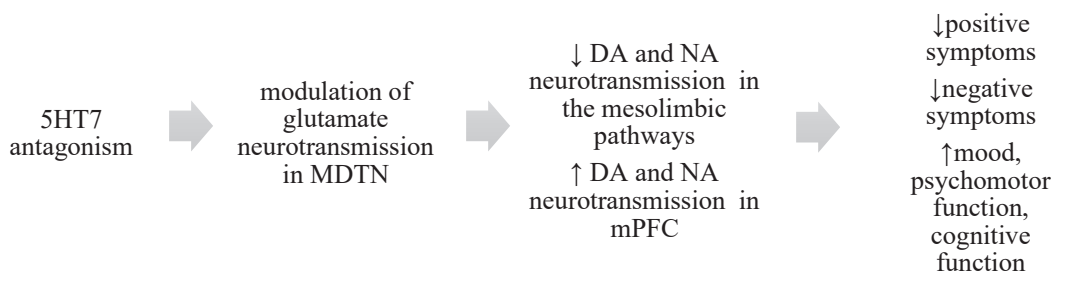

*DA - dopamin, NA - noradrenaline, MDTN - mediodorsal thalamic nucleus, mPFC - medial prefrontal cortex

Figure 5. The plausible mechanism underlying the influence of lurasidone on clinical symptoms in patients 
effect on the activity of 5HT1A and 5HT7 receptors, may also be linked with the $\mathrm{D} 2$ receptor blockade in connection with a low - as compared to other APDs - inhibition of D4 receptors (Mauri et al., 2018). The study on marmosets revealed that lurasidone facilitated the improvement of results in a test which evaluated the cognitive functions performed by monkeys, and the effect was intensified once the D4 receptor agonist (Ro10-5824) was administered to the animals. However, the animals which were administered with lurasidone and the $\mathrm{D} 4$ receptor blocking agent L-745, 870 achieved worse results in the cognitive functioning test than those who received only the medication (Murai et al., 2014).

Inhibition of a 2 receptors, which is linked with promoting the noradrenergic and serotoninergic transmission (activity analogous to mirtazapine), may be an additional (apart from the effect on 5HT2, 5HT7 and 5HT1A receptors) and significant mechanism which may facilitate the anti-depressive effect of lurasidone.

The above anti-depressive and pro-cognitive effect of lurasidone at the level of clinical symptoms and results of neuroimaging is reflected in the study by Wolke et al. (2019). The study recruited individuals presenting with various degrees of depressive symptomatology those with no such symptoms and patients with major depression. After a single dose, i.e. $20 \mathrm{mg}$ of lurasidone, functional magnetic resonance imaging and a monetary incentive delay task were conducted. The results of this study (Fig. 6) revealed that lurasidone normalises the functioning of the reward system in the group of depression patients (Wolke et al., 2019).

Table 2 presents the receptor activity of lurasidone which conditions its efficacy in various symptomatic areas as well as conclusions regarding the clinical application of this medication.

\section{Lurasidone receptor profile vs. adverse effects}

Table 3 presents the relationship between the antagonism to chosen receptors and adverse effects of antipsychotic therapy.

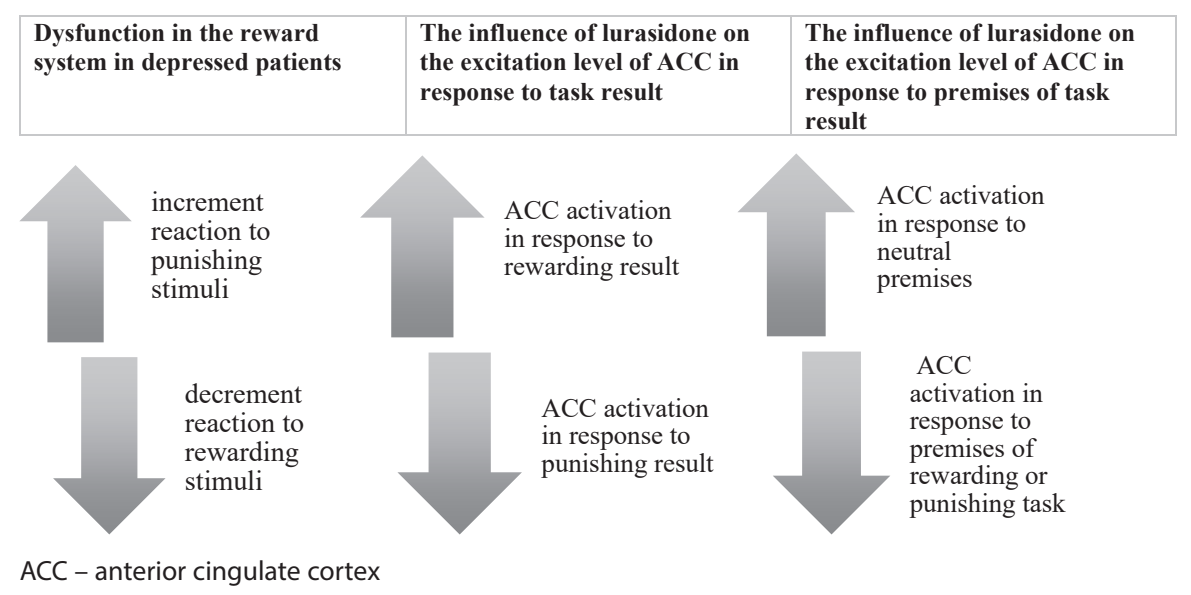

Figure 6. The reward system dysfunction observed in depressed patients and the influence of lurasidone on the reward system

Table 2. A relationship between the receptor activity of lurasidone and the observed effects of therapy and therapeutic recommendations resulting from them

\begin{tabular}{|c|c|c|}
\hline Receptor activity & Effect & Therapeutic usefulness \\
\hline D2 antagonism & $\downarrow$ dopaminergic transmission in mesolimbic pathways & $\begin{array}{l}\downarrow \text { positive symptoms observed in schizophrenia } \\
\text { and affective disorders with psychotic features }\end{array}$ \\
\hline $5 \mathrm{HT} 2 \mathrm{~A}$ antagonism & $\uparrow$ dopaminergic transmission in mesocortical pathways & $\downarrow$ negative and depression symptoms \\
\hline High inhibition ratio D2 / D4 & $\begin{array}{l}\text { The mechanism is unclear, it is assumed that it is } \\
\text { connected with modulation of dopaminergic and } \\
\text { noradrenergic transmission in PFC }\end{array}$ & $\uparrow$ cognitive and executive functioning \\
\hline $\begin{array}{l}\text { Partial agonism of } 5 \mathrm{HT} 1 \mathrm{~A} \\
\text { autoreceptors }\end{array}$ & $\begin{array}{l}\uparrow \text { Facilitation of serotoninergic transmission in DRN, } \\
\text { MDTN and PFC }\end{array}$ & $\downarrow$ depression and potentially anxiety symptoms \\
\hline 5HT7 antagonism & $\begin{array}{l}\text { Facilitation of serotoninergic transmission in DRN, } \\
\text { MDTN and PFC } \\
\text { Glutamatergic, dopaminergic and catecholaminergic } \\
\text { transmission modulation in the thalamus and PFC }\end{array}$ & $\begin{array}{l}\uparrow \text { cognitive functioning } \\
\downarrow \text { depression symptoms } \\
\text { potentially } \downarrow \text { positive and negative symptoms of } \\
\text { psychosis }\end{array}$ \\
\hline a2 antagonism & $\uparrow$ noradrenergic and serotoninergic transmission & $\downarrow$ depression symptoms \\
\hline
\end{tabular}


Lurasidone has a negligible affinity for muscarinic receptors; therefore, the therapy with this medication is characterised by a very low risk of adverse effects related to cholinergic transmission inhibition, such as xerostomia, accommodation disturbances, tachycardia, constipation or difficulties with passing/holding urine. Thanks to very weak binding of H1, 5HT2C and M3 receptors, lurasidone therapy creates a negligible risk of somnolence, increased appetite and weight gain, unfavourable changes in lipid profile or carbohydrate metabolism. Furthermore, due to a moderate affinity for $\alpha 1$ receptors, the application of lurasidone is connected with a relatively low (as compared to APDs with a high affinity for al) probability of orthostatic hypotension (Greenberg and Citrome, 2016; Citrome, 2011).

Tabela 3. Intrinsic activity of APDs towards chosen receptors and related adverse effects of the therapy (Solmi et al., 2017; Olten and Bloch, 2018)

\begin{tabular}{|ll}
\hline Blocked receptor & $\begin{array}{l}\text { Adverse effects resulting from receptor } \\
\text { blockade }\end{array}$ \\
& $\begin{array}{l}\text { Extrapyramidal symptoms, } \\
\text { hyperprolactinemia, sexual dysfunctions, } \\
\text { decreased cognitive function }\end{array}$ \\
5HT2C & $\begin{array}{l}\text { Increased appetite and weight gain, } \\
\text { development of features of metabolic } \\
\text { a1 }\end{array}$ \\
syndrome \\
H1 \\
Orthostatic hypotonia, retrograde \\
ejaculation, hypoactive sexual desire \\
Hypersomnia, decreased cognitive \\
function increased appetite and weight \\
gain \\
Decreased cognitive function, xerostomia, \\
tachycardia, increased intraocular pressure, \\
constipation, holding urine \\
\end{tabular}

\section{Pharmacokinetics}

Lurasidone is available in the form of oral tablets in the following doses: $18.5 \mathrm{mg}, 37 \mathrm{mg}$ and $74 \mathrm{mg}$, to be taken once a day. This medication is poorly soluble in water and it is absorbed from the alimentary tract only to a limited degree when taken orally. There have been two open-label studies which included patients suffering from schizophrenia or schizoaffective disorders in which lurasidone absorption rate was evaluated depending on the administration of the medication with food (or not) as well caloricity and content of the meal. In the first trial, it was observed that a high-calorie meal (800-1000 kcal) eaten with lurasidone was associated with a considerable increase of bioavailability of the pharmaceutic as compared to administration of the medication on empty stomach or with a low-calorie meal (100-200 kcal) (Greenberg and Citrome, 2016). In another study, lurasidone bioavailability was compared when administered on empty stomach or with food containing $350 \mathrm{kcal}$ (high amount of fat), $500 \mathrm{kcal}$ or $800-1000 \mathrm{kcal}$ (with high or low amount of fat). Also in this trial the lurasidone absorption rate increase was observed if the medication was administered with food. There were no significant differences in absorption in terms of caloricity of the food: 350/500/800-1000, and there were no significant discrepancies after low- or high-fat meals. As a result, it is recommended to take lurasidone with a meal of 350 $\mathrm{kcal}$ and optional fat content - in these conditions bioavailability of this medicine is 9-19\% (Preskorn et al., 2013). This form of administration ensures the confirmed clinical efficacy of the medication in the range between 40 and $160 \mathrm{mg}$ daily in the therapy of schizophrenia in adults. Calorific value of a meal that should be eaten to achieve a satisfactory absorption level is lower for lurasidone $(350 \mathrm{kcal})$ than ziprasidone $(500 \mathrm{kcal})$, which should make it easier for patients to administer the medication properly (Sutton et al., 2017). At present, lurasidone is available only in the form of tablets containing CHL crystals. Both in a single or multiple oral administration of the medication, the peak serum concentration (Tmax) is achieved within $1.5-3 \mathrm{~h}$, and biological half-life (T1/2) is $18.1-25.5 \mathrm{~h}$ for doses of 20-80 daily and 28.8-37.4 $\mathrm{h}$ for 120-160 mg daily (Hu et al., 2017; Meyer et al., 2009). After 7 days of lurasidone therapy, the steady-state is achieved. Lurasidone, administered within recommended doses, in the form of hydrochloride - 20-160 mg daily - is characterized by linear pharmacokinetics. This means that therapeutic effect of this medication depends on administered dose, which was reflected in the studies conducted among schizophrenia patients (Loebel et al., 2016; Leucht et al., 2019). Lurasidone is $99.8 \%$ bound to plasma proteins. The principal route of lurasidone metabolism is in the liver, mainly by CYP3A4 enzymes and this drug is affected by the first pass effect. Main derivatives of lurasidone metabolism exert analogous effect on receptors to the basic form of medication, however, their share in achieving therapeutic effect seems to be negligible (Mauri et al., 2018). The medication is eliminated in the faeces (67-80\%) and, to a lesser degree, in urine (9-19\%) (Latuda ChPL; Sunovion Pharmaceuticals Inc. Latuda). Furthermore, studies were conducted to evaluate the lurasidone pharmacokinetics in chosen patient populations: with hepatic or renal failure. The results are collected in Table 5 . In the trials no significant effect of age, race or sex of patients was observed on the lurasidone pharmacokinetics. In elderly individuals ( $>65$ years old) medicine concentration is approximately $20 \%$ higher than in young adults, however, the therapy does not require dose modifications. Furthermore, Findling et al. (2015) conducted a study in the group of 105 children aged 6-17 to evaluate the pharmacokinetic properties of lurasidone in the youth population. Within the range of administered doses of 20-160 mg daily in the form of hydrochloride, 
similarly to previously discussed data, lurasidone is characterised by linear pharmacokinetics. Tmax was $2 \mathrm{~h}$ and steady-state was achieved after approximately 10 days of therapy (for $160 \mathrm{mg}$ daily, after 12 days). The exposure to the drug was also similar to the adult population (Findling et al., 2015). Data on lurasidone pharmacokinetics is collected in Table 4.

Table 4. Pharmacokinetic properties of lurasidone in the form of hydrochloride

\begin{tabular}{|c|c|}
\hline $\begin{array}{l}\text { Time to } \\
\text { maximum serum } \\
\text { concentration }\end{array}$ & $1.5-3$ hours \\
\hline $\begin{array}{l}\text { Biological half-life } \\
\text { time }\end{array}$ & $\begin{array}{l}\text { Dose: } 20-80 \mathrm{mg} / \text { day }-18.1-25.5 \text { hours; dose: } \\
120-160 \mathrm{mg} / \text { day }-28.8-37.4 \text { hours }\end{array}$ \\
\hline $\begin{array}{l}\text { Time to } \\
\text { steady-state }\end{array}$ & 7 days (10-12 for children) \\
\hline Pharmacokinetics & $\begin{array}{l}\text { Dose: } 20-160 \mathrm{mg} / \text { day; linear dependency } \\
\text { dose-effect }\end{array}$ \\
\hline Metabolism & Liver by CYP3A4; first pass effect \\
\hline Elimination & Faeces (67-80\%); urine (9-19\%) \\
\hline Age $>65$ & $\uparrow$ Serum concentration by $20 \%$ \\
\hline
\end{tabular}

\section{Interactions with other medications and substances}

Lurasidone does not exhibit a significant inhibitory effect on particular CYP450 isoenzymes; therefore, the risk of interactions resulting from liver metabolism blockade of another co-administered medication should be recognised as negligible. As an exception to this rule there are medications which - similarly to lurasidone - are almost entirely metabolised by CYP3A4/3A5 (e.g. amlodipine, lercanidipine). In such a case, there is a potential risk that lurasidone will compete with the abovementioned medications for liver metabolism, which may result in their increased concentrations and the risk of adverse effects. However, it should be noted that so far such an interaction for lurasidone has not been described in literature (Siwek, 2020). Lurasidone should not be combined with strong CYP3A4 inhibitors due to the risk of considerable inhibition of its metabolism which may lead to its increased concentration with a subsequent escalation of adverse effects or manifestation of toxicity (Table 6). If other medications which manifest a moderate ability to block CYP3A4 are administered together with lurasidone, it should be remembered that lurasidone dose must be corrected - the therapy should commence with $18.5 \mathrm{mg}$ daily and the maximum dose of $74 \mathrm{mg}$ daily should not be exceeded (Chiu et al., 2014; Citrome, 2013). In the course of lurasidone therapy, grapefruit, pomelo or greater amounts of oranges should be eliminated from the diet. Bergamottin, naringin or naringenin, which can be found in these fruits, might significantly inhibit the activity of CYP3A4 (Woroń and Siwek, 2018; Wasik et al., 2019). Factors which may reduce the lurasidone concentration with a subsequent weakening or even losing its clinical action include all strong CYP3A4 inductors, such as rifampicin, carbamazepine, glucocorticosteroids, barbiturates, modafinil or melatonin (Spina et al., 2016; Woroń et al., 2019; Chiu et al., 2014; Siwek 2020). Due to the fact that lurasidone significantly blocks P-glycoproteins, it can increase digoxin concentration and a potential risk of digoxin-generated adverse effects (Woroń et al., 2019). However, due to a low risk of organ toxicity and a negligible affinity for histamine, muscarine or $\alpha$-adrenergic receptors, combining lurasidone with other medications is linked to very low risk of pharmacodynamic interactions (Siwek, 2020).

Table 5. Lurasidone pharmacokinetics in the group of patients with hepatic or renal failure and clinical implications (hydrochloride form of lurasidone)

\begin{tabular}{|c|c|c|c|}
\hline Population & $\begin{array}{l}\text { Cmax as compared } \\
\text { to healthy } \\
\text { individuals }\end{array}$ & $\begin{array}{l}\text { AUC as compared } \\
\text { to healthy } \\
\text { individuals }\end{array}$ & Required therapy modifications \\
\hline \multicolumn{4}{|l|}{$\begin{array}{l}\text { Hepatic } \\
\text { failure: }\end{array}$} \\
\hline Mild & $\uparrow 26 \%$ & $\uparrow 35-49 \%$ & - \\
\hline Moderate & $\uparrow 20 \%$ & $\uparrow 66-75 \%$ & $\begin{array}{l}\text { Starting dose } 20 \mathrm{mg} / \text { day, maximum dose should not exceed } 80 \mathrm{mg} / \mathrm{day} \text {, } \\
\text { respectively }\end{array}$ \\
\hline Severe & $\uparrow 35 \%$ & $\uparrow 300 \%$ & $\begin{array}{l}\text { Starting dose } 20 \mathrm{mg} / \text { day, maximum dose should not exceed } 40 \mathrm{mg} / \text { day, } \\
\text { respectively }\end{array}$ \\
\hline \multicolumn{4}{|l|}{ Renal failure: } \\
\hline Mild & $\uparrow 40 \%$ & $\uparrow 53 \%$ & - \\
\hline Moderate & $\uparrow 92 \%$ & $\uparrow 91 \%$ & \multirow{2}{*}{$\begin{array}{l}\text { Starting dose } 20 \mathrm{mg} / \text { day, maximum dose should not exceed } 80 \mathrm{mg} / \text { day, } \\
\text { respectively }\end{array}$} \\
\hline Severe & $\uparrow 54 \%$ & $\uparrow 103 \%$ & \\
\hline
\end{tabular}


Table 6. Chosen CYP3A4 inhibitors (following: Wishart et al., 2018; Law et al., 2014; Woroń et al., 2019; Woroń and Siwek, 2018)

\begin{tabular}{|c|c|}
\hline \multicolumn{2}{|c|}{ Chosen CYP3A4 inhibitors } \\
\hline Strong & Moderate \\
\hline Atazanavir* & Aprepitant \\
\hline Boceprevir & Danazol \\
\hline Cobicistat & Diltiazem* \\
\hline Darunavir & Fluvoxamine \\
\hline Delavirdine & Fluoxetine* \\
\hline Efavirenz & Fosamprenavir \\
\hline Erythromycin & Fosnetupitant \\
\hline Fluconazole & Isradipine \\
\hline Idelalisib & Isoniazid \\
\hline Indinavir & Clarithromycin \\
\hline Itraconazole & Curcumin \\
\hline Ketoconazole* & Kratom \\
\hline Lopinavir & Fusidic acid \\
\hline Midostaurin & Lovastatin \\
\hline Nefazodone & Luliconazole \\
\hline Nelfinavir & Miconazole \\
\hline Nilotinib & Netupitant \\
\hline Posaconasole & Nicardipine \\
\hline Ritonavir & Primaquine \\
\hline Saquinavir & Simeprevir \\
\hline Troleandomycin & Ticonazole \\
\hline Voriconazol & $\begin{array}{l}\text { Tricyclic antidepressants } \\
\text { Verapamil }\end{array}$ \\
\hline
\end{tabular}

\section{Wstęp}

Obecnie dostępnych jest wiele leków przeciwpsychotycznych (LPP), stanowiących podstawę leczenia schizofrenii oraz choroby afektywnej dwubiegunowej. Jednak, pomimo wielu lat badań i znacznej różnorodności LPP, u znacznej części pacjentów nie udaje się osiągnąć zadowalających wyników leczenia. Wynika to w dużej mierze z niewystarczającej skuteczności LPP w zakresie redukcji objawów wytwórczych, negatywnych, zaburzeń funkcji poznawczych czy objawów depresyjnych. Ponadto obecnie stosowane LPP często charakteryzują się takim profilem działań niepożądanych, który jest powodem odstawiania leków przez pacjenta bądź utrudnia osiągnięcie remisji funkcjonalnej (Gorostowicz i wsp., 2020). W związku z tym nieustannie trwają prace nad syntezą i oceną nowych, coraz skuteczniejszych i bezpieczniejszych LPP (Carpenter i Davis, 2012). Jednym ze stosunkowo niedawno wprowadzonych do stosowania LPP jest lurasidon. Przedmiotem tej pracy będzie zwięzłe omówienie właściwości farmakodynamicznych i farmakokinetycznych lurasidonu oraz potencjalnych interakcji związanych z jego stosowaniem.

\section{Summary}

The above-discussed pharmacodynamic and pharmacokinetic properties of lurasidone suggest a very good safety and tolerance profile and its efficacy in the therapy of a broad spectrum of schizophrenia symptoms (positive, negative and depressive symptoms and cognitive dysfunctions), as well as mood-stabilising properties of the medication. All these aspects of lurasidone action have been subjects of clinical trials and were confirmed. At present, the European Medicines Agency approves the use of lurasidone in the treatment of adults with schizophrenia. In the USA and Canada, lurasidone is registered - beside the adult schizophrenia pharmacotherapy - to treat major depression episodes among adults and teenagers (13-17 years old) diagnosed with BD type I in a monotherapy or as an adjuvant medicine in the therapy with lithium or valproate acid, and also to treat schizophrenia in adolescents (ChPL Latuda; Sunovion Pharmaceuticals Inc. Latuda; Latuda Prescribing Information).

\section{Struktura i właściwości farmakodynamiczne lurasidonu}

Lurasidon jest atypowym lekiem przeciwpsychotycznym, należącym do pochodnych piperazyny, podobnie jak aripiprazol lub ziprazidon (rycina 1).

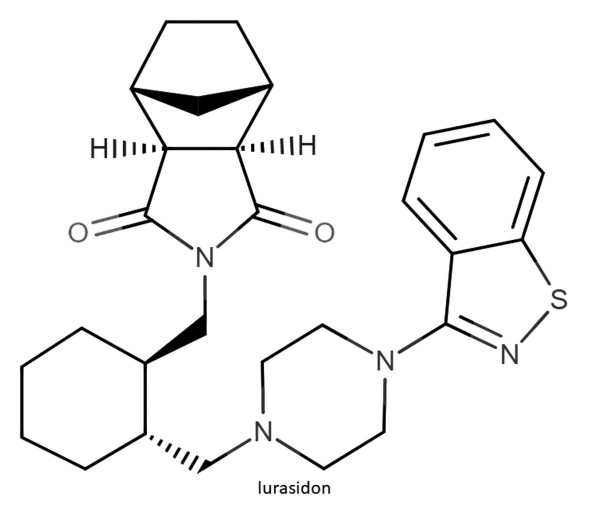

Rycina 1. Wzór strukturalny lurasidonu (Wishart et al., 2018) 
Profil działania lurasidonu na receptory przedstawiono na rycinie 2 . W tabeli 1 porównano profil receptorowy lurasidonu z wybranymi najnowszymi oraz powszechnie stosowanymi LPP.

Lurasidon jest silnym antagonistą receptorów D2, a jego powinowactwo do tego receptora jest około 3-krotnie większe niż haloperidolu i nawet 20 -krotnie większe niż olanzapiny. W badaniach z zastosowaniem obrazowania pozytronowej tomografii emisyjnej (positron emission tomography, PET) oceniano stopień wysycenia receptorów D2. Wong i wsp. (2013) badali zdrowych mężczyzn, którym jednorazowo podano lurasidon w dawkach 10-80 mg. Wyniki PET wskazały, że poziom związania receptorów D2 był podobny w obszarach: brzusznej części prążkowia, skorupie oraz jądrze ogoniastym i wynosił, w zależności od podanej dawki: $10 \mathrm{mg}$ - 41-43\%, $20 \mathrm{mg}$
- 51-55\%, $40 \mathrm{mg}-63-67 \%, 60 \mathrm{mg}-77-84 \%, 80 \mathrm{mg}-$ 73-79\%. Wśród badanych, którzy przyjęli dawki 10-60 mg farmaceutyku, obserwowano zależność pomiędzy stopniem wysycenia receptorów D2 lurasidonem a stężeniem leku, a także jego podstawowego metabolitu w surowicy badanych (Wong i wsp., 2013). Także Potkin i wsp. (2014) przeprowadzili badanie z zastosowaniem obrazowania PET. Objęło ono chorych ze schizofrenią lub zaburzeniem schizoafektywnym. Uczestnicy otrzymywali lurasidon w dawce 80, 120 lub $160 \mathrm{mg}$ na dobę. Wyniki wskazały na znamienną zależność między poziomem wysycenia receptorów D2 w podkorowych strukturach mózgu a poziomem lurasidonu w surowicy; efekt ten był największy w przypadku gałki bladej, nieco mniejszy w jądrze ogoniastym, skorupie, wzgórzu, jądrze migdałowatym i najmniejszy w jądrze półleżącym. Jak opisywali

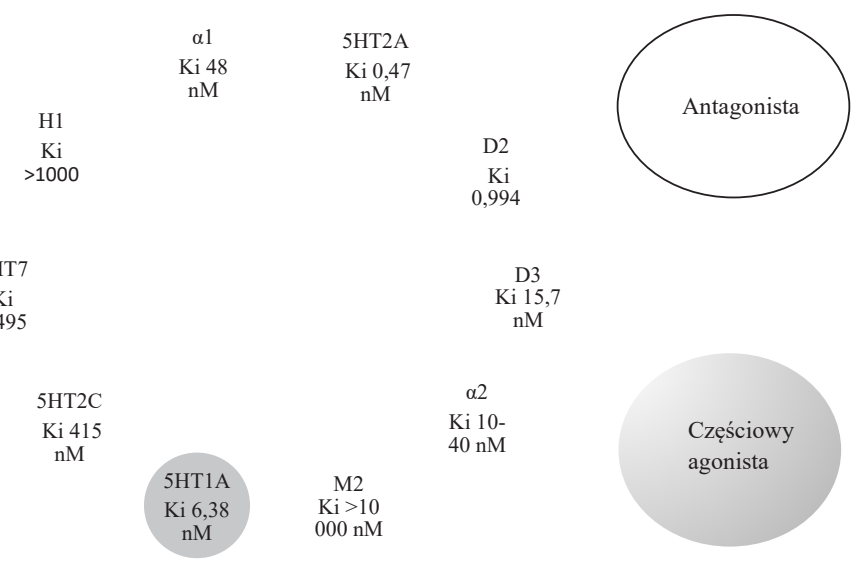

Rycina 2. Powinowactwo i aktywność wewnętrzna lurasidonu do receptorów monoamin i muskarynowych

Tabela 1. Właściwości farmakodynamiczne lurasidonu i wybranych LPP (Solmi i wsp., 2017; Das i wsp., 2016; Roth i wsp., 2004; Frankel i Schwartz, 2017; Citrome, 2015; Andressen i wsp., 2015; Tyler i wsp., 2017; Olten i Bloch, 2018)

\begin{tabular}{|c|c|c|c|c|c|c|c|}
\hline \multirow[t]{2}{*}{ Receptor } & \multicolumn{7}{|c|}{ Leki przeciwpsychotyczne } \\
\hline & Lurasidon & Brekspiprazol & Kariprazyna & Aripiprazol & Risperidon & Olanzapina & Haloperidol \\
\hline D2 & $++++(-)$ & $++++(+/-)$ & $++++(+/-)$ & $++++(+/-)$ & $+++(-)$ & $++(-)$ & $+++(-)$ \\
\hline D3 & $++(-)$ & $+++(+/-)$ & $++++(+/-)$ & $++++(+/-)$ & ++ & $+++\backslash++(-)$ & $+++\backslash++(--)$ \\
\hline $5-\mathrm{HT} 1 \mathrm{~A}$ & $+++(+/-)$ & $++++(+/-)$ & $+++(+/-)$ & $+++(+/-)$ & $+(-)$ & + (inhibicja?) & - \\
\hline $5-\mathrm{HT} 2 \mathrm{~A}$ & $++++(-)$ & $++++(-)$ & $+++(-)$ & $+++(-)$ & $++++(-)$ & $+++(-)$ & $++(-)$ \\
\hline $5-\mathrm{HT} 2 \mathrm{~B}$ & $?$ & $+++(-)$ & $++++(-)$ & $++++(--)$ & $++/+(-)$ & $?$ & $?$ \\
\hline $5-\mathrm{HT} 2 \mathrm{C}$ & $+(-)$ & $++(-)$ & $+(-)$ & $++(+/-)$ & $++(-)$ & $++(-)$ & - \\
\hline 5-HT7 & $++++(-)$ & $+++(-)$ & $+(-)$ & $++(+/-)$ & $++++/+++(-)$ & $++/+(--)$ & $++/+$ \\
\hline a1 & $++(-)$ & $++++/+++(-)$ & $++(-)$ & $++(-)$ & $+++(-)$ & $++(-)$ & $++(-)$ \\
\hline$a 2 \mathrm{~A}$ & $++(-)$ & $++(-)$ & $?$ & \multirow[t]{2}{*}{$++(-)$} & \multirow[t]{2}{*}{$+++(-)$} & \multirow[t]{2}{*}{$+(-)$} & \multirow[t]{2}{*}{+} \\
\hline$a_{2 C}$ & $++(-)$ & $++++(-)$ & $?$ & & & & \\
\hline $\mathrm{H} 1$ & $-(-)$ & $++(-)$ & $++(-)$ & $++(-)$ & $+++(-)$ & $++++(-)$ & + \\
\hline M2 & $-(-)$ & $-(-)$ & $-(-)$ & $-(-)$ & $-(-)$ & $+(-)$ & - \\
\hline M3 & $-(-)$ & $?$ & $?$ & $-(-)$ & $-(-)$ & $+(-)$ & $-(-)$ \\
\hline
\end{tabular}


Nordstrom i wsp. (1993), Farde i wsp. (1995) czy Mamo i wsp. (2004), działanie przeciwpsychotyczne LPP jest obserwowane po osiągnięciu ok. $65 \%$ związania receptorów D2 zlokalizowanych w strukturach podkorowych. Obliczenia Potkina i wsp. (2014) wskazały, że aby uzyskać takie wysycenie receptorów D2, stężenie lurasido$\mathrm{nu}$ (wraz z jego główną pochodną ID-14283) w surowicy powinno być większe niż $70 \mathrm{ng} / \mathrm{ml}$. Dodatkowo, w ocenie po tygodniu stosowania lurasidonu, odnotowano istotną zależność pomiędzy poziomem wysycenia receptorów D2 zlokalizowanych w strukturach podkorowych a redukcją nasilenia objawów pozytywnych i negatywnych (Potkin i wsp., 2014) Na rycinie 3 przedstawiono schemat obrazujący związek pomiędzy zaburzeniami neurotransmisji dopaminergicznej a objawami, jakich doświadczają chorzy na schizofrenię.

W przypadku osób cierpiących z powodu objawów pozytywnych, zarówno w przebiegu schizofrenii, jak i manii, poziom transmisji dopaminergicznej w szlakach mezolimbicznych jest podwyższony. Dzięki blokowaniu receptorów D2 lurasidon (podobnie jak większość innych atypowych LPP o udowodnionej skuteczności) pozwala obniżyć nasilenie przekaźnictwa zależnego od dopaminy, dzięki czemu zaobserwować można jego działanie przeciwwytwórcze. Wśród pacjentów doświadczających objawów negatywnych i zaburzeń poznawczych w toku schizofrenii oraz takich symptomów depresji, jak anhedonia, spowolnienie psychoruchowe, wycofanie z relacji, obniżenie motywacji i poziomu funkcji wykonawczych, można natomiast odnotować osłabienie transmisji dopaminowej w szlakach mezokortykalnych. Dzięki hamowaniu receptorów serotoninowych 5HT2A lurasidon (tak jak inne atypowe LPP) promuje mezokortykalne przekaźnictwo dopaminergiczne i w efekcie redukuje wyżej wymienione objawy negatywne schizofrenii oraz symptomy depresji. Blokada receptorów 5HT2A ma także wpływ na funkcjonowanie transmisji dopaminergicznej w innych szlakach opartych na sygnalizacji dopaminowej: 1) nigrostriatalnym, którego hamowanie wiąże się z rozwojem objawów pozapiramidowych, 2) guzkowo-lejkowym, w przypadku którego spadek aktywności dopaminowej wiąże się z ryzykiem hiperprolaktynemii. Hamowanie przekaźnictwa dopaminowego w związku z blokadą receptorów D2 jest więc częściowo znoszone dzięki wzmagającemu transmisję dopaminergiczną hamowaniu receptorów 5HT2A. W efekcie leczenie lurasidonem charakteryzuje się stosunkowo niskim (w porównaniu np. do ujętych w tabeli risperidonu czy haloperidolu) ryzykiem rozwoju takich działań niepożądanych, jak objawy pozapiramidowe czy hiperprolaktynemia. Jednak ryzyko to jest większe niż np. w przypadku kwetiapiny, olanzapiny czy klozapiny (Greenberg i Citrome, 2016; Solmi i wsp., 2017; Mamo i wsp., 2004).

Lurasidon, poza wyżej wymienionymi cechami farmakodynamicznymi, jest częściowym agonistą receptorów 5HT1A. Znane są 2 rodzaje receptorów 5HT1A: autoreceptory zlokalizowane na błonie presynaptycznej neuronów wychodzących z jąder grzbietowych szwu (dorsal raphe nuceli, DRN), gdzie ich aktywacja wiąże się z obniżeniem przekaźnictwa serotoninowego oraz heteroreceptory błon postsynaptycznych neuronów glutaminergicznych i GABA-ergicznych układu limbicznego i przyśrodkowej kory przedczołowej (medial prefrontal cortex, mPFC). Częściowo agonistyczne działanie lurasidonu na autoreceptory 5HT1A w DRN wiąże się z następczą ich desensytyzacją/downregulacją i torowaniem przekaźnictwa serotoninowego, co stanowi jeden z głównych mechanizmów rozwoju efektu przeciwdepresyjnego. W nieco innym mechanizmie, poprzez zwiększenie ilości serotoniny w szczelinie synaptycznej, do downregulacji receptorów 5HT1A dochodzi także w następstwie stosowania leków z grupy selektywnych inhibitorów wychwytu zwrotnego serotoniny / serotoniny i noradrenaliny. Z kolei wpływ lurasidonu na heteroreceptory 5HT1A błon postsynaptycznych komórek glutaminergicznych i GABA-ergicznych w układzie limbicznym i mPFC może częściowo odpowiadać za efekt prokognitywny, a także przeciwpsychotyczny (Okada i wsp., 2019a). Takekita i wsp. (2015) opublikowali metaanalizę badań posługujących się metodą GWAS (Genome Wide Association Studies - badania $\mathrm{z}$ sekwencjonowaniem całego genomu), wskazującą na znaczenie polimorfizmu genu receptora 5HT1A dla odpowiedzi na leczenie przeciwpsychotyczne w zaostrzeniu schizofrenii. Yoshikawa i wsp. (2019) przeprowadzili metaanalizę trzech badań, w których weryfikowano skuteczność terapii schizofrenii z zastosowaniem lurasidonu (oraz dwóch oceniających skuteczność innych LPP w tym wskazaniu), również opierając się na metodzie GWAS. Wyniki ich pracy potwierdziły istotną zależność pomiędzy polimorfizmem 5HT1A a redukcją
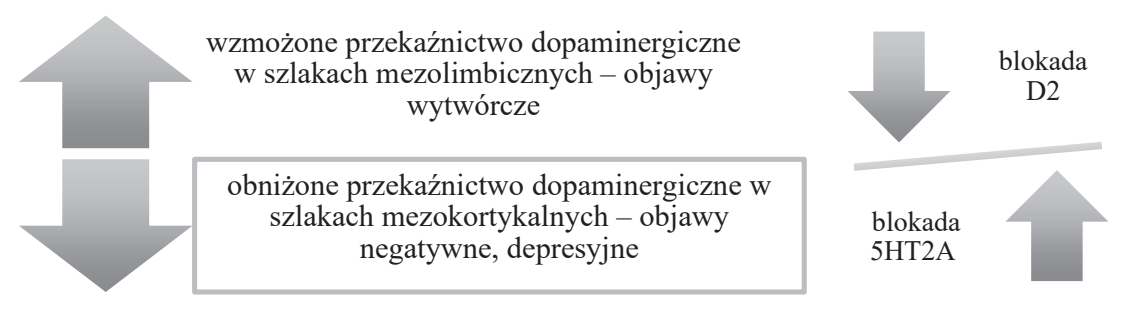

Rycina 3. Zależność poziomu przekaźnictwa w szlakach dopaminergicznych i obrazu klinicznego pacjenta oraz wpływ lurasidonu na układ dopaminergiczny 
punktacji w Skali Objawów Pozytywnych i Negatywnych w populacji pochodzenia europejskiego, ale nie afrykańskiego (Yoshikawa i wsp., 2019).

Lurasidon jest silnym antagonistą receptorów 5HT7, co stanowi jeden z ważnych mechanizmów warunkujących jego działanie podnoszące nastrój i prowadzące do poprawy funkcji poznawczych (podobnie do wortioksetyny) (Greenberg i Citrome, 2016). Aktywność neuronów serotoninergicznych i GABA-ergicznych w DRN jest ograniczana, w przeważającej mierze, przez autoreceptory 5HT1A, natomiast stymulacja transmisji GABA-ergicznej jest zależna przede wszystkim od agonizmu receptorów 5HT7 (rycina 4). Mechanizm działania lurasidonu w tych obszarach szczegółowo badali Okada i wsp. (2019a). Przeprowadzili oni badanie na szczurach, którym podawali lurasidon oraz inne cząsteczki modyfikujące działanie receptorów serotoninowych lub NMDA, a następnie oceniali, za pomocą metody chromatografii, transmisję serotoninergiczną $\mathrm{w}$ DRN, przyśrodkowogrzbietowym jądrze wzgórza (mediodorsal thalamic nucleus, MDTN) i MPFC oraz przekaźnictwo związane z GABA w DRN. Obserwowali, że podanie w okolice DRN SB269970 (antagonisty 5HT7) lub lurasidonu (także stosowanego systemowo) prowadziło do odhamowania GABA-ergicznego, ale nie wiązało się ze wzmożeniem transmisji serotoninergicznej w DRN, MDTN czy mPFC. Natomiast podanie w okolice DRN substancji hamującej receptory NMDA (MK-801) prowadziło poprzez obniżenie aktywności hamujących neuronów GABA-ergicznych do znacznego nasilenia uwalniania serotoniny. $\mathrm{Z}$ kolei podanie lurasidonu równocześnie z substancją blokującą receptory 5HT1A (WAY100635) prowadziło do zależnego od dawki leku wzrostu przekaźnictwa serotoninowego, co wskazuje, że częściowy agonizm receptorów autoreceptorów 5HT1A zapobiega nadmiernemu nasilaniu transmisji serotoninergicznej. Powyżej omówione wyniki wskazują, że do promocji przekaźnictwa serotoninergicznego przez lurasidon konieczne jest jego równoczesne oddziaływanie na receptory 5HT1A i 5HT7, dzięki któremu dochodzi do ich desensytyzacji i osłabienia hamowania transmisji zależnej od serotoniny, a ponadto do torowania przekaźnictwa glutaminergicznego w układzie limbicznym i mPFC (rycina 4), (Okada i wsp., 2019a).

Hamowanie receptorów 5 HT7 jest też związane ze skutecznością lurasidonu w obszarze objawów negatywnych i wytwórczych. W patofizjologii schizofrenii pewną rolę, choć jeszcze nie do końca poznaną, odgrywa neurotransmisja glutaminergicza. Już w XX wieku obserwowano, że stosowanie antagonistów receptora NMDA (receptor $\mathrm{N}$-metylo-D-asparaginowy - receptor dla glutaminianu selektywnie aktywowany przez kwas N-metylo-D-asparaginowy, NMDA), fencyklidyny, ketaminy, prowadziło u osób zdrowych do rozwoju zarówno pozytywnych, jak i negatywnych objawów schizofrenii (Malhotra i wsp., 1996). Dane naukowe pochodzące $z$ badań in vitro oraz przeprowadzanych na zwierzętach wskazują, że lurasidon, działając antagonistycznie na receptory $5 \mathrm{HT} 7$, w pośredni sposób moduluje przekaźnictwo glutaminergiczne (Okada i wsp., 2019b). Wzgórze, z którego wysyłane są projekcje glutaminergiczne do wyspy oraz kory przedczołowej, jest strukturą, w której licznie reprezentowane są receptory 5HT7 (Hedlund i Sutcliffe, 2004; Gogolla, 2017). Z kolei wyspa posiada liczne połączenia funkcjonalne ze strukturami podkorowymi, jak również korowymi kontrolującymi percepcję bodźców zmysłowych, emocje, motywacje czy funkcjonowanie poznawcze. Zaburzenia neurotransmisji w wyspie związane są zarówno z pozytywnymi, jak i negatywnymi objawami schizofrenii (Tian i wsp., 2019; Wylie, Tregellas, 2010). W badaniu Okady i wsp. przeprowadzonym na szczurach oceniano przekaźnictwo w MDTN (przyśrodkowogrzbietowym jądrze wzgórza) oraz wyspie po podaniu szczurom MK-801 (antagonisty NMDA) lub lurasidonu w okolice jednej lub obydwu tych struktur. Wyniki tej pracy wskazują, że lurasidon wywiera wpływ modulujący przekaźnictwo glutaminergiczne Regulacja transmisji serotoninergicznej
w DRN
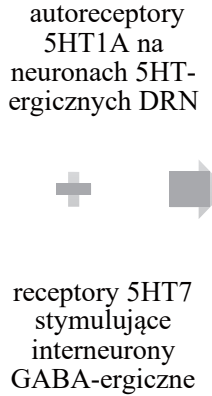

$\downarrow$ przekaźnictwa serotoninowego w DRN, MDTN, $\mathrm{mPFC}$

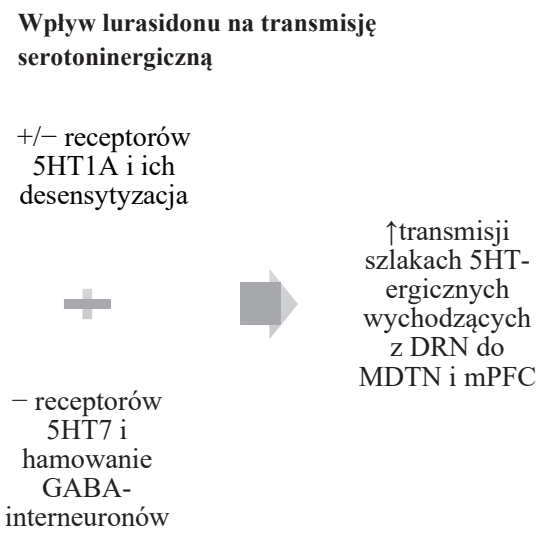

(+/(+/-) - częściowy agonizm, (-) - antagonizm, $\uparrow$ - wzmożenie, $\downarrow$ - ograniczenie, 5HT - serotonina, DRN - jądro grzbietowe szwu, MDTN - jądro przyśrodkowo-grzbietowe wzgórza, mPFC - przyśrodkowa kora przedczołowa

Rycina 4. Wpływ lurasidonu na mechanizmy kontrolujące przekaźnictwo serotoninergiczne 
w sposób pośredni, poprzez hamowanie receptorów $5 \mathrm{HT7}$ zlokalizowanych we wzgórzu (Okada i wsp., 2019b). Dostępne dane świadczą też o tym, że modulujący wpływ lurasidonu na przekaźnictwo glutaminergiczne, oprócz hamowania $5 \mathrm{HTT}$, jest zależny także od częściowego agonizmu 5HT1A (Huang i wsp., 2018).

Podsumowując, wyniki wcześniej omówionych prac wskazują, że blokada receptorów 5 HT7 poprzez modulację przekaźnictwa glutaminergicznego wywiera działanie ograniczające neurotransmisję dopaminergiczną oraz noradrenergiczną w szlakach mezolimbicznych oraz promujące transmisję katecholaminergiczną w szlakach mezokortykalnych (rycina 5). Dodatkowo, dzięki przeprowadzonym na zwierzętach próbom, można wywnioskować, że efekt ten jest zależny od częściowego agonizmu lurasidonu wobec receptorów 5HT1A.

Prokognitywne działanie lurasidonu (Harvey i wsp., 2013; Harvey i wsp., 2015; Harvey i wsp., 2016), poza wpływem na aktywność receptorów 5HT1A i 5HT7, może być też związane z blokadą receptorów D2 w połączeniu z niskim w porównaniu do innych LPP hamowaniem receptorów D4 (Mauri i wsp., 2018). W badaniach przeprowadzonych na marmozetach odnotowano, że stosowanie lurasidonu przyczyniało się do poprawy wyników wykonywanego przez małpy testu oceniającego funkcje poznawcze, a efekt ten był potęgowany przez podanie zwierzętom agonisty receptorów D4 (Ro10-5824). Natomiast zwierzęta, które przyjmowały lurasidon oraz blokującą receptory D4 substancję L-745, 870, osiągały gorsze wyniki w teście mierzącym funkcjonowanie poznawcze niż te, który otrzymały tylko lek (Murai i wsp., 2014).

Dodatkowym (obok wpływu na receptory 5HT2, 5HT7 i 5HT1A) i bardzo istotnym mechanizmem mogącym przyczyniać się do efektu przeciwdepresyjnego wywieranego przez lurasidon może być hamowanie receptorów a2 wiążące się z promowaniem przekaźnictwa noradrenergicznego i serotoninergicznego (działanie analogicznie do mirtazapiny).

Wyżej omówione działanie przeciwdepresyjne i prokognitywne lurasidonu na poziomie objawów klinicznych i wyników neuroobrazowych odzwierciedla praca Wolke i wsp. (2019). W badaniu uczestniczyły osoby wykazujące różny poziom dolegliwości depresyjnych - od wolnych od takich objawów, aż po chorych z dużą depresją. Po podaniu pojedynczej dawki - 20 mg lurasido$\mathrm{nu}$ - przeprowadzano badanie funkcjonalnego rezonansu magnetycznego oraz zadanie z odroczoną gratyfikacją. Wyniki tej pracy (rycina 6) wskazały, że lurasidon normalizuje funkcjonowanie układu nagrody w grupie pacjentów z depresją (Wolke i wsp., 2019).

W tabeli 2 przedstawiono działania receptorowe lurasidonu warunkujące jego skuteczność w różnych obszarach objawowych oraz wynikające $z$ tych danych wnioski dotyczące stosowania leku.

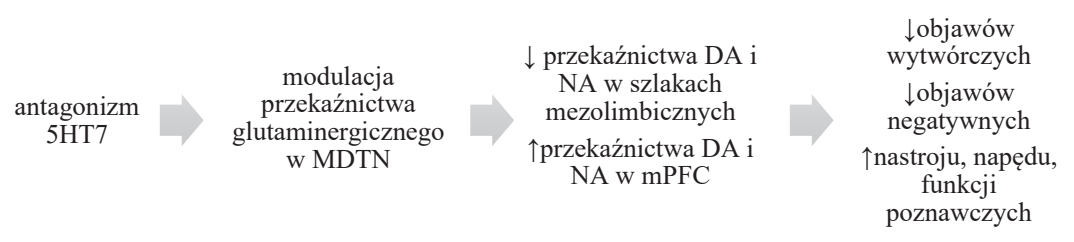

DA - dopamina, NA - noradrenalina, MDTN - jądro przyśrodkowo-grzbietowe wzgórza, mPFC - przyśrodkowa kora przedczołowa

Rycina 5. Przypuszczalny mechanizm wpływu hamowania receptorów $5 \mathrm{HT7}$ przez lurasidon na obraz kliniczny obserwowany u pacjenta

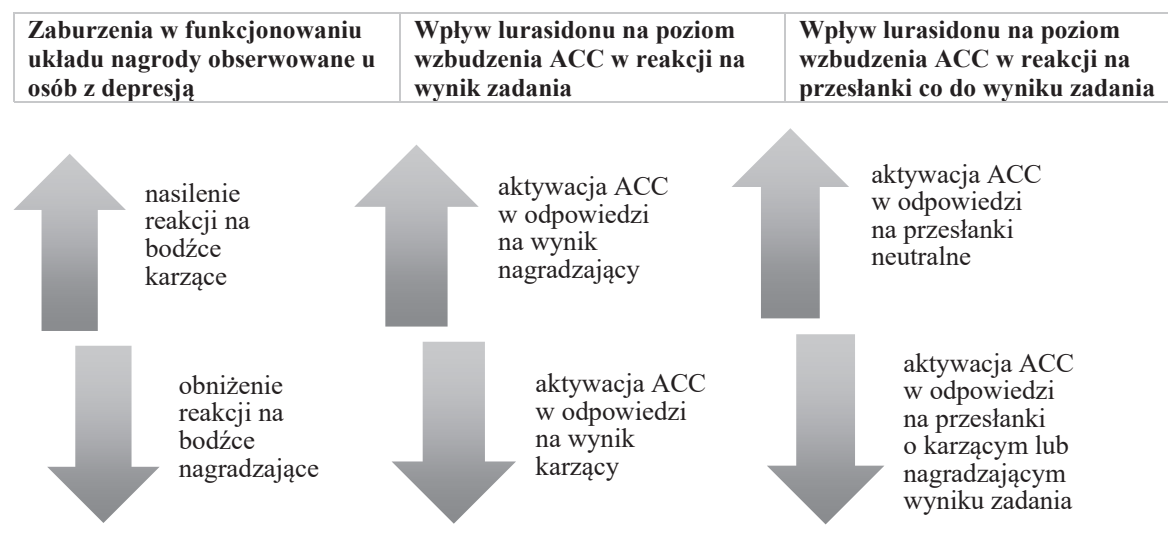

ACC - kora zakrętu obręczy

Rycina 6. Nieprawidłowości funkcjonowania układu nagrody typowe dla pacjentów z depresją oraz wpływ, jaki lurasidon wywiera na działanie układu nagrody 
Tabela 2. Związek między receptorowym działaniem lurasidonu a obserwowanymi efektami leczenia oraz wynikające z nich wskazania terapeutyczne

\begin{tabular}{|c|c|c|}
\hline Działanie receptorowe & Efekt & Przydatność w leczeniu \\
\hline antagonizm D2 & $\begin{array}{l}\downarrow \text { transmisji dopaminergicznej w szlakach } \\
\text { mezolimbicznych }\end{array}$ & $\begin{array}{l}\downarrow \text { objawów wytwórczych obserwowanych } \\
\text { w schizofrenii i zaburzeń afektywnych } \\
\text { z towarzyszącymi objawami psychotycznymi }\end{array}$ \\
\hline antagonizm $5 \mathrm{HT} 2 \mathrm{~A}$ & $\begin{array}{l}\uparrow \text { transmisji dopaminergicznej w szlakach } \\
\text { mezokortykalnych }\end{array}$ & $\downarrow$ objawów negatywnych oraz depresyjnych \\
\hline $\begin{array}{l}\text { wysoki stosunek hamowania } \\
\text { D2 / D4 }\end{array}$ & $\begin{array}{l}\text { mechanizm niejasny, przypuszcza się, że związany } \\
\text { z modulacją transmisji dopaminergicznej } \\
\text { i noradrenergicznej w korze przedczołowej }\end{array}$ & $\uparrow$ funkcjonowania poznawczego, wykonawczego \\
\hline $\begin{array}{l}\text { częściowy agonizm } \\
\text { autoreceptorów } 5 \mathrm{HT} 1 \mathrm{~A}\end{array}$ & $\begin{array}{l}\uparrow \text { torowania przekaźnictwa serotoninergicznego } \\
\text { w DRN, MDTN i PFC }\end{array}$ & $\downarrow$ objawów depresyjnych i potencjalnie lękowych \\
\hline antagonizm $5 \mathrm{HT7}$ & $\begin{array}{l}\text { torowanie przekaźnictwa serotoninergicznego } \\
\text { w DRN, MDTN i PFC } \\
\text { modulacja przekaźnictwa glutaminergicznego, } \\
\text { dopaminergicznego i katecholaminergicznego } \\
\text { w wyspie i PFC }\end{array}$ & $\begin{array}{l}\uparrow \text { funkcjonowania poznawczego } \\
\downarrow \text { objawów depresyjnych } \\
\text { potencjalnie } \downarrow \text { pozytywnych i negatywnych } \\
\text { objawów psychozy }\end{array}$ \\
\hline antagonizm a2 & $\uparrow$ transmisji noradrenergicznej i serotoninergicznej & $\downarrow$ objawów depresyjnych \\
\hline
\end{tabular}

\section{Profil receptorowy lurasidonu a działania niepożądane}

$\mathrm{W}$ tabeli 3 przedstawiono związek antagonizmu wobec wybranych receptorów z występowaniem działań niepożądanych leczenia przeciwpsychotycznego.

Tabela 3. Aktywność wewnętrzna LPP wobec wybranych receptorów i związane z nią działania niepożądane leczenia (Solmi i wsp., 2017; Olten i Bloch, 2018)

\begin{tabular}{|c|c|}
\hline $\begin{array}{l}\text { Blokowany } \\
\text { receptor }\end{array}$ & $\begin{array}{l}\text { Działania niepożądane będące efektem } \\
\text { blokowania receptora }\end{array}$ \\
\hline D2 & $\begin{array}{l}\text { objawy pozapiramidowe, hiperprolaktynemia, } \\
\text { zaburzenia funkcji seksualnych, obniżenie } \\
\text { funkcjonowania poznawczego }\end{array}$ \\
\hline $5 \mathrm{HT} 2 \mathrm{C}$ & $\begin{array}{l}\text { wzrost apetytu i masy ciała, rozwój cech zespołu } \\
\text { metabolicznego }\end{array}$ \\
\hline a1 & $\begin{array}{l}\text { hipotonia ortostatyczna, wsteczna ejakulacja, } \\
\text { obniżenie popędu seksualnego }\end{array}$ \\
\hline $\mathrm{H} 1$ & $\begin{array}{l}\text { senność, obniżenie funkcjonowania poznawczego, } \\
\text { wzrost apetytu i masy ciała }\end{array}$ \\
\hline M2 & $\begin{array}{l}\text { obniżenie funkcjonowania poznawczego, } \\
\text { suchość w ustach, tachykardia, wzrost ciśnienia } \\
\text { śródgałkowego, zaparcia, zatrzymanie moczu }\end{array}$ \\
\hline M3 & insulinooporność \\
\hline
\end{tabular}

Lurasidon wykazuje znikome powinowactwo do receptorów muskarynowych, dlatego terapię tym lekiem cechuje bardzo niskie ryzyko działań niepożądanych związanych $\mathrm{z}$ hamowaniem transmisji cholinergicznej, takich jak: suchość w ustach, zaburzenia akomodacji, tachykardia, osłabienie perystaltyki czy trudności w oddawaniu/zatrzymaniu moczu. Dzięki bardzo słabemu wiązaniu receptorów H1, 5HT2C i M3 leczenie lurasidonem stwarza znikome ryzyko senności, wzrostu apetytu i wzrostu masy ciała czy niekorzystnych zmian profilu lipidowego lub gospodarki węglowodanowej. Ponadto, z uwagi na umiarkowane powinowactwo do receptorów $\alpha 1$, stosowanie lurasidonu wiąże się ze stosunkowo niskim (w porównaniu z LPP o wysokim powinowactwie do al) prawdopodobieństwem wystąpienia ortostatycznych spadków ciśnienia tętniczego (Greenberg i Citrome, 2016; Citrome, 2011).

\section{Farmakokinetyka}

Lurasidon jest dostępny w postaci tabletek doustnych w dawkach 18,5 mg, 37 mg, 74 mg, które należy zażywać $1 \mathrm{raz}$ dziennie. Lek ten cechuje się niską rozpuszczalnością w wodzie i jest jedynie w ograniczonym stopniu wchłaniany z przewodu pokarmowego po przyjęciu drogą doustną. Przeprowadzono dwa badania otwarte, obejmujące chorych ze schizofrenią lub zaburzeniem schizoafektywnym, w których oceniano absorpcję lurasidonu w zależności od przyjęcia (lub nie) razem z lekiem posiłku oraz jego kaloryczności i składu. W pierwszej próbie odnotowano, że spożycie wysokokalorycznego posiłku (800-1000 kcal), równocześnie z zażyciem lurasidonu, w porównaniu z przyjęciem leku na czczo lub z pokarmem niskokalorycznym (100-200 kcal), wiązało się ze znamiennym wzrostem biodostępności farmaceutyku (Greenberg i Citrome, 2016). W kolejnym badaniu porównano biodostępność lurasidonu w warunkach przyjęcia leku na czczo lub z pokarmem o zawartości $350 \mathrm{kcal}$ (z dużą zawartością tłuszczu, 500 kcal lub 800-1000 kcal (z wysoką lub niską zawartością tłuszczu). Także w tej próbie obserwowano wzrost wchłaniania lurasidonu w warunkach spożycia posiłku równocześnie z zażyciem leku. Nie wykazano istotnych różnic w absorpcji leku 
w warunkach po spożyciu pokarmów o kaloryczności 350/500/800-1000, nie odnotowano także znamiennych odmienności po przyjęciu posiłków o niskiej lub wysokiej zawartości tłuszczu. W efekcie zaleca się, aby zażywać lurasidon z posiłkiem o wartości energetycznej $350 \mathrm{kcal}$ o dowolnej zawartości tłuszczu - w tych warunkach biodostępność leku wynosi około 9-19\%. (Preskorn i wsp., 2013). Taka forma przyjęcia leku zapewnia udowodnioną w badaniach skuteczność kliniczną leku w zakresie dawek od 40 do $160 \mathrm{mg}$ na dobę w leczeniu schizofrenii u dorosłych. Kaloryczność posiłku, który należy spożyć, aby osiągnąć zadowalający poziom absorpcji farmaceutyku, jest niższa w wypadku lurasidonu (350 kcal) niż ziprazidonu (500 kcal), co powinno ułatwić pacjentom prawidłowe stosowanie leku (Sutton i wsp., 2017). Obecnie lurasidon dostępny jest w leczeniu jedynie w postaci tabletek zawierających kryształy CHL. Zarówno w przypadku jednorazowego, jak i wielokrotnego przyjęcia doustnego czas do osiągnięcia maksymalnego stężenia leku w surowicy (Tmax) waha się w zakresie 1,5-3 godziny, a biologiczny okres półtrwania ( $\mathrm{T} 1 / 2)$ wynosi $18,1-25,5$ godziny w zakresie dawek $20-80 \mathrm{mg}$ na dobę i 28,8-37,4 godziny w przypadku dawkowania 120-160 mg na dobę (Hu i wsp., 2017; Meyer i wsp., 2009). Po 7 dniach zażywania lurasidonu dochodzi do ustalenia stanu stacjonarnego. Lurasidon stosowany w obrębie zalecanych dawek, w postaci chlorowodorku - 20-160 mg na dobę - wykazuje farmakokinetykę liniową. Oznacza to, że efekt terapeutyczny leku jest zależny od przyjmowanej przez pacjenta dawki, co znajduje potwierdzenie w badaniach przeprowadzonych wśród chorych z rozpoznaniem schizofrenii (Loebel i wsp., 2016; Leucht i wsp., 2019). Lek w $99,8 \%$ łączy się z białkami surowicy. Lurasidon w znacznej mierze podlega metabolizmowi wątrobowemu, głównie przez enzymy CYP3A4, oraz efektowi pierwszego przejścia. Główne pochodne metabolizmu lurasidonu wywierają analogiczne do podstawowej formy leku działanie na receptory, jednak ich udział w osiąganiu efektu terapeutycznego wydaje się znikomy (Mauri i wsp., 2018). Lek jest wydalany ze stolcem (67-80\%) i w znacznie mniejszym stopniu z moczem (9-19\%), (Latuda ChPL; Sunovion Pharmaceuticals Inc. Latuda). Przeprowadzono także badania oceniające farmakokinetykę lurasidonu w wybranych populacjach chorych: z niewydolnością wątroby lub nerek. Wyniki tych badań zebrano w tabeli 5 . W prowadzonych próbach nie obserwowano znamiennego wpływu wieku, rasy czy płci leczonych na farmakokinetykę lurasidonu. U osób w wieku podeszłym (>65 lat) stężenie leku jest około $20 \%$ wyższe niż u młodych dorosłych, jednak nie wiąże się to z koniecznością modyfikacji w postępowaniu terapeutycznym. Ponadto Findling i wsp. (2015) przeprowadzili, w grupie 105 dzieci w wieku 6-17 lat, badanie oceniające właściwości farmakokinetyczne lurasidonu w populacji młodzieżowej. W zakresie stosowanych dawek, w postaci chlorowodorku, 20-160 mg na dobę, podobnie jak we wcześniej omówionych danych, lurasidon cechowała farmakokinetyka liniowa. Tmax wyniósł 2 godziny. Stan stacjonarny osiągano po około 10 dniach stosowania leku (w przypadku dawki $160 \mathrm{mg}$ na dzień dopiero po 12 dniach). Ekspozycja na lek również była podobna jak w populacji dorosłych (Findling i wsp., 2015). Dane charakteryzujące farmakokinetykę lurasidonu podsumowano w tabeli 4.

Tabela 4. Właściwości farmakokinetyczne lurasidonu w postaci chlorowodorku

\begin{tabular}{|c|c|}
\hline $\begin{array}{l}\text { Czas do osiągnięcia } \\
\text { maksymalnego } \\
\text { stężenia w surowicy }\end{array}$ & 1,5-3 godziny \\
\hline $\begin{array}{l}\text { Czas biologicznego } \\
\text { półtrwania leku }\end{array}$ & $\begin{array}{l}\text { dawkowanie: } 20-80 \mathrm{mg} / \text { dobę - } \\
\text { 18,1-25,5 godziny dawkowanie: } \\
\text { 120-160 mg/dobę - 28,8-37,4 godziny }\end{array}$ \\
\hline $\begin{array}{l}\text { Czas do osiągnięcia } \\
\text { stanu stacjonarnego }\end{array}$ & 7 dni (10-12 w przypadku dzieci) \\
\hline Farmakokinetyka & $\begin{array}{l}\text { dawkowanie: } 20-160 \mathrm{mg} / \text { dobę liniowa } \\
\text { zależność dawka-efekt }\end{array}$ \\
\hline Metabolizm & $\begin{array}{l}\text { wątrobowy przez CYP3A4 } \\
\text { efekt pierwszego przejścia }\end{array}$ \\
\hline Wydalanie & ze stolcem $(67-80 \%)$, z moczem (9-19\%) \\
\hline Wiek $>65$ lat & 个stężenia w surowicy o 20\% \\
\hline
\end{tabular}

Tabela 5. Farmakokinetyka lurasidonu w grupach pacjentów z niewydolnością wątroby lub nerek oraz implikacje lecznicze (w postaci chlorowodorku lurasidonu)

\begin{tabular}{|c|c|c|c|}
\hline Populacja & $\begin{array}{l}\text { Cmax w porównaniu } \\
\text { do osób zdrowych }\end{array}$ & $\begin{array}{l}\text { AUC w porównaniu } \\
\text { do osób zdrowych }\end{array}$ & Wymagane modyfikacje w leczeniu \\
\hline \multicolumn{4}{|c|}{ niewydolność wątroby: } \\
\hline lekka & $\uparrow 26 \%$ & $\uparrow 35-49 \%$ & - \\
\hline umiarkowana & $\uparrow 20 \%$ & $\uparrow 66-75 \%$ & $\begin{array}{l}\text { rozpoczynać od } 20 \mathrm{mg} / \text { dobę, a maksymalna dawka leku nie } \\
\text { powinna przekroczyć kolejno } 80 \mathrm{mg} / \text { dobę }\end{array}$ \\
\hline ciężka & $\uparrow 35 \%$ & $\uparrow 300 \%$ & $\begin{array}{l}\text { rozpoczynać od } 20 \mathrm{mg} / \text { dobę, a maksymalna dawka leku nie } \\
\text { powinna przekroczyć kolejno } 40 \mathrm{mg} / \text { dobę }\end{array}$ \\
\hline \multicolumn{4}{|c|}{ niewydolność nerek: } \\
\hline lekka & $\uparrow 40 \%$ & $\uparrow 53 \%$ & - \\
\hline umiarkowana & $\uparrow 92 \%$ & $\uparrow 91 \%$ & \multirow{2}{*}{$\begin{array}{l}\text { rozpoczynać od } 20 \mathrm{mg} / \text { dobę, a maksymalna dawka leku nie } \\
\text { powinna przekroczyć kolejno } 80 \mathrm{mg} / \text { dobę }\end{array}$} \\
\hline ciężka & $\uparrow 54 \%$ & $\uparrow 103 \%$ & \\
\hline
\end{tabular}




\section{Interakcje z innymi lekami i substancjami}

Lurasidon nie wykazuje istotnego działania hamującego wobec poszczególnych izoenzymów CYP450, a zatem ryzyko interakcji wynikających z blokady metabolizmu wątrobowego innego, łącznie stosowanego leku, należy uznać za znikome. Wyjątek stanowić mogą leki, które - podobnie do lurasidonu - metabolizowane są prawie wyłącznie przy udziale CYP3A4/3A5 (np. amlodipina, lerkanidipina). W takiej sytuacji istnieje potencjalne ryzyko, że lurasidon będzie konkurować z wyżej wymienionymi lekami o metabolizm wątrobowy, czego skutkiem może być wzrost ich stężenia i ryzyka działań niepożądanych. Należy jednak podkreślić, że do tej pory, w przypadku lurasidonu, nie opisano przypadków ww. interakcji (Siwek, 2020). Lurasidonu raczej nie powinno się łączyć z silnymi inhibitorami CYP3A4, ze względu na ryzyko znaczącego zahamowania jego metabolizmu, mogące prowadzić do wzrostu jego stężenia z następową eskalacją działań niepożądanych lub ujawnieniem się toksyczności (tabela 6). W przypadku równoczesnego stosowania leków o umiarkowanej zdolności blokowania CYP3A4 należy pamiętać o konieczności korekty dawki lurasidonu - leczenie powinno się rozpocząć od dawki 18,5 mg dziennie oraz nie należy przekraczać dawki dobowej 74 mg (Chiu i wsp., 2014; Citrome, 2013). W trakcie leczenia lurasidonem $\mathrm{z}$ diety pacjenta powinno się wyeliminować grejpfruty, pomelo czy większe ilości pomarańczy. Zawarte w nich bergamotyna, naryngina czy naryngenina mają bowiem zdolność do istotnej blokady aktywności CYP3A4 (Woroń i Siwek, 2018; Wasik i wsp., 2019). Czynnikami mogącymi powodować obniżenie stężenia lurasidonu z następowym osłabieniem, a nawet utratą działania klinicznego są wszelkie silne induktory CYP3A4 - takie jak np. ryfampicyna, karbamazepina, glikokortykosteroidy, barbiturany, modafinil czy melatonina (Spina i wsp., 2016; Woroń i wsp., 2019; Chiu i wsp., 2014; Siwek, 2020). Ze względu na to, że lurasidon w sposób istotny blokuje P-glikoproteiny, może on powodować wzrost stężenia digoksyny i potencjalny wzrost ryzyka generowanych przez nią działań niepożądanych (Woroń i wsp., 2019). Natomiast ze względu na niskie ryzyko toksyczności narządowych oraz nikłe powinowactwo do receptorów histaminowych, muskarynowych czy a-adrenergicznych łączenie lurasidonu z innymi lekami obarczone jest bardzo niskim ryzykiem interakcji farmakodynamicznych (Siwek, 2020).

Conflict of interest and non declared. / Nie zgłoszono konfliktu interesów.

The work described in this article has been carried out in accordance with The Code of Ethics of the World Medical Association (Declaration of Helsinki) for experiments involving humans, EU Directive 2010/63/EU for animal experiments, and
Tabela 6. Wybrane inhibitory CYP3A4 (na podstawie: Wishart i wsp., 2018; Law i wsp., 2014; Woroń i wsp., 2019; Woroń i Siwek, 2018)

\begin{tabular}{|c|c|}
\hline \multicolumn{2}{|c|}{ Wybrane inhibitory CYP3A4 } \\
\hline \multicolumn{2}{|c|}{ Silne Umiarkowane } \\
\hline Atazanawir* & $\begin{array}{ll}\text { ine } & \text { Umiarkowane } \\
\text { tazanawir* } & \text { Aprepitant }\end{array}$ \\
\hline Boceprewir & Danazol \\
\hline Kobicystat & Diltiazem* \\
\hline Darunawir & Fluwoksamina \\
\hline Delawirdyna & Fluoksetyna* \\
\hline Efawirenz & Fosamprenawir \\
\hline Erytromycyna & Fosnetupitant \\
\hline Flukonazol & Isradypina \\
\hline Idelalizyb & Izoniazyd \\
\hline Indinawir & Klarytromycyna \\
\hline Itrakonazol & Kurkumina \\
\hline Ketokonazol* & Kratom \\
\hline Lopinawir & Kwas fusydowy \\
\hline Midostaurin & Lowastatyna \\
\hline Nefazodon & Lulikonazol \\
\hline Nelfinawir & Mikonazol \\
\hline Nilotynib & Netupitant \\
\hline Posakonazol & Nikardipina \\
\hline Ritonawir & Prymachina \\
\hline Sakwinawir & Simeprewir \\
\hline Troleandomycyna & Tikonazol \\
\hline Worikonazol & $\begin{array}{l}\text { Trójpierścieniowe leki przeciwdepresyjne } \\
\text { Werapamil }\end{array}$ \\
\hline
\end{tabular}

\section{Podsumowanie}

Wyżej omówione właściwości farmakodynamiczne i farmakokinetyczne lurasidonu sugerują bardzo dobry profil bezpieczeństwa i tolerancji oraz skuteczność w leczeniu szerokiego spektrum objawów schizofrenii (objawy wytwórcze, negatywne, depresyjne i zaburzenia funkcji poznawczych), a także właściwości normotymiczne leku. Wszystkie te aspekty działania lurasidonu były przedmiotem badań klinicznych i znalazły swoje potwierdzenie. W chwili obecnej Europejska Agencja Leków dopuszcza leczenie lurasidonem wśród osób dorosłych ze schizofrenią. W USA i Kanadzie lurasidon zarejestrowany jest, obok farmakoterapii schizofrenii u dorosłych, w leczeniu epizodów dużej depresji wśród osób dorosłych oraz nastolatków (13-17 lat) z rozpoznaniem ChAD typu I w monoterapii bądź jako lek uzupełniający leczenie litem lub kwasem walproinowym, a także w leczeniu schizofrenii wśród adolescentów (ChPL Latuda; Sunovion Pharmaceuticals Inc. Latuda; Latuda Prescribing Information).

Uniform Requirements for manuscripts submitted to biomedical journals. / Treści przedstawione w artykule są zgodne z zasadami Deklaracji Helsińskiej, dyrektywami EU oraz ujednoliconymi wymaganiami dla czasopism biomedycznych.

Authors' contributions / Wkład autorów: MS - 40\%; AJK - 50\%; AW $-10 \%$. 


\section{References / Piśmiennictwo}

1. Andressen KW, Manfra O, Brevik CH, Ulsund AH, Vanhoenacker P, Levy FO, et al. The atypical antipsychotics clozapine and olanzapine promote down-regulation and display functional selectivity at human 5-HT 7 receptors. British Journal of Pharmacology 2015; 172: 3846-3860. doi: 10.1111/bph.13169.

2. Carpenter WT and Davis JM. Another view of the history of antipsychotic drug discovery and development, Molecular Psychiatry. Nature Publishing Group 2012; 17(12): 1168-1173. doi: $10.1038 / \mathrm{mp} .2012 .121$.

3. Charakterystyka Produktu Leczniczego: Latuda.

4. Chiu YY, Ereshefsky L, Preskorn SH, Poola N, Loebel A. Lurasidone drug-drug interaction studies: a comprehensive review. Drug. Metabol. Drug. Interact. 2014: 29(3): 191-202. https://doi.org/10.1515/dmdi-2014-0005.

5. Citrome L. Iloperidone, Asenapine, and Lurasidone: A Brief Overview of 3 New Second-Generation Antipsychotics. Postgraduate Medicine 2011; 123(2): 153-162.

6. Citrome LA. Review of the pharmacology, efficacy and tolerability of recently approved and upcoming oral antipsychotics: an evidence-based medicine approach. CNS Drugs 2013; 27(11): 879-911; https://doi.org/10.1007/s40263-013-0105-7.

7. Citrome L. The ABC's of dopamine receptor partial agonists - aripiprazole , brexpiprazole and cariprazine: the 15-min challenge to sort these agents out. Int J Clin Pract 2015; 69(11): 1211-1220.

8. Das S, Barnwal P, Winston A B, Mondal S, Saha I. Brexpiprazole: so far so good. Ther Adv Psychopharmacol 2016; 6(1):39-54. doi: 10.1177/2045125315614739.

9. Farde, L, Nyberg S, Oxenstierna G, Nakashima Y, Halldin C, Ericsson B. Positron Emission Tomography Studies on D2 and 5HT2 Receptor Binding in Risperidone-treated Schizophrenic Patients', Journal of Clinical Psychopharmacology1995;15(1): 19-23.

10. Findling RL, Chiu YY, Silva R, Jin F, Pikalov, et al. (2015). Pharmacokinetics and Tolerability of Lurasidone in Children and Adolescents With Psychiatric Disorders', Clinical Therapeutics. Elsevier 201537(12): 2788-2797. Doi: 10.1016/j. clinthera.2015.11.001.

11. Frankel JS, Schwartz T L. Brexpiprazole and cariprazine: distinguishing two new atypical antipsychotics from the original dopamine stabilizer aripiprazole', Therapeutic Advances in Psychopharmacology 2017; 7(1): 29-41. Doi: $10.1177 / 2045125316672136$.

12. Gogolla N. The insular cortex. Current Biology. Elsevier 2017; 27(12), pp. R580-R586. Doi: 10.1016/j.cub.2017.05.010.

13. Gorostowicz A, Wasik A, Siwek M. Wyzwania współczesnej farmakoterapii schizofrenii i choroby afektywnej dwubiegunowej. W: Nowe leki przeciwpsychotyczne (red. Siwek M), Medical Education, Warszawa 2020, s. 9-22.

14. Greenberg WM, Citrome L. Pharmacokinetics and Pharmacodynamics of Lurasidone Hydrochloride, a Second-Generation Antipsychotic: A Systematic Review of the Published Literature. Clinical Pharmacokinetics. Springer International Publishing 2016. Doi: 10.1007/s40262-016-0465-5.

15. Harvey PD, Siu CO, Hsu J, Cucchiaro J, Maruff P, Loebel A. Effect of lurasidone on neurocognitive performance in patients with schizophrenia: A short-term placebo- and active-controlled study followed by a 6-month double-blind. European Neuropsychopharmacology. Elsevier 2013; 23(11): 1373-1382. Doi: 10.1016/j.euroneuro.2013.08.003.

16. Harvey PD, Siu CO, Ogasa M, Loebel A. Effect of lurasidone dose on cognition in patients with schizophrenia : Post-hoc analysis of a long-term, double-blind continuation study. Schizophrenia Research. Elsevier B.V.2015; 166(1-3): 334338. Doi: 10.1016/j.schres.2015.06.008.

17. Harvey PD, Siu CO and Loebel AD. Change in daytime sleepiness and cognitive function in a 6-month, double-blind study of lurasidone and quetiapine XR in patients with schizophrenia', Schizophrenia Research: Cognition. The Authors 2016; 5: 7-12. Doi: 10.1016/j.scog.2016.05.002.

18. Hedlund PB, Sutcliffe JG. Functional, molecular and pharmacological advances in 5-HT 7 receptor research', TRENDS in Pharmacological Sciences 2004; 25(9): 5-10; Doi: 10.1016/j. tips.2004.07.002.

19. Hu, C, Wang Y, Song R, Yu C, Luo X, Jia J. Single- and Multiple-Dose Pharmacokinetics, Safety and Tolerability of Lurasidone in Healthy Chinese Subjects', Clinical Drug Investigation. Springer International Publishing, (966) 2017. Doi: 10.1007/s40261-017-0546-8.

20. Huang M, Kwon S, Rajagopal L, He W, Meltzer HY, et al. 5-HT 1A parital agonism and 5-HT 7 antagonism restore episodic memory in subchronic phencyclidine-treated mice: role of brain glutamate , dopamine, acetylcholine and GABA', Psychopharmacology 2018; 235(10): 2795-2808.

21. Jaeschke R, Sowa-Kućma M, Pańczyszyn-Trzewik P, Misztak P, Styczeń K, Datka W. Pharmacological Reports Lurasidone: The 2016 update on the pharmacology , efficacy and safety profile, Pharmacological Reports xxx 2016; 68(4): 748-55. Doi: 10.1016/j.pharep.2016.04.002.

22. Latuda Prescribing Information (2012).

23. Law V, Knox C, Djoumbou Y, Jewison T, Guo ACh, Liu Y. DrugBank 4.0: shedding new light on drug metabolism. Nucleic Acids Res 2014; 42(1): D1091-1097.

24. Leucht, S. Crippa A, Siafis S, Patel MX, Orsini N, Davis JM. Dose-Response Meta-Analysis of Antipsychotic Drugs for Acute Schizophrenia. American Journal of Psychiatry 2019; 1-12. Doi: 10.1176/appi.ajp.2019.19010034.

25. Loebel AD, Silva R, Goldman R, Watabe K, Cucchiaro J, Citrome L, et al. Lurasidone Dose Escalation in Early Nonresponding Patients With Schizophrenia: A Randomized, Placebo-Controlled Study', Journal of Clinical Psychiatry 2016; 77: 1672-1680.

26. Malhotra AK, Pinals DA, Weingartner H, Sirocco K, Missar CD, Pickar D, et al. NMDA Receptor Function and Human Cognition: The Effects of Ketamine in Healthy Volunteers. Neuropsychopharmacology 1996; (14): 301-307.

27. Mamo D, Kapur S, Shammi CM, Papatheodorou G, Mann S, et al. A PET Study of Dopamine D 2 and Serotonin 5-HT 2 Receptor Occupancy in Patients With Schizophrenia Treated With Therapeutic Doses of Ziprasidone', Am J Psychiatry 2004; 161: 818-825.

28. Meyer JM, Loebel $\mathrm{AD}$ and Schweizer E. Lurasidone: a new drug in development for schizophrenia. Expert Opin Investig Drugs 2009; 18(11): 1715-1726.

29. Mauri MC, et al. (2018). 'Clinical Pharmacokinetics of Atypical Antipsychotics: An Update', Clinical Pharmacokinetics. Springer International Publishing, 2018. Doi: 10.1007/ s40262-018-0664-3.

30. Murai T, Nakako T, Ikeda K, Ikejiri M, Ishiyama T, Taiji M. Lack of dopamine D4 receptor affinity contributes to the precognitive effect of lurasidone', Behavioural Brain Research. Elsevier B.V. 2015; 261: 26-30. Doi: 10.1016/j.bbr.2013.11.036.

31. Nordstrom A, Farde L, Wiesel FA, Forslund K, Pauli S, Halldin C, et al. Central D2-Dopamine Receptor Occupancy in Relation to Antipsychotic Drug Effects: A Double- Blind PET Study of Schizophrenic Patients. Biol Psychiatry 1993; 33: 227-235. 
32. Okada M, Fukuyama K, Okubo R, Shiroyama T, Yuto Ueda Y. Lurasidone Sub-Chronically Activates Serotonergic Transmission via Desensitization of 5-HT1A and 5-HT7 Receptors in Dorsal Raphe Nucleus. Pharmaceuticals 2019; 12 (149) (a).

33. Okada M, Fukuyama K, Ueda Y. Lurasidone inhibits NMDA receptor antagonist - induced functional abnormality of thalamocortical glutamatergic transmission via 5 -HT 7 receptor blockade. Br J Pharmacol 2019; 1-17. Doi: 10.1111/ bph.14804 (b).

34. Olten B, Bloch $\mathrm{MH}$. Meta regression: Relationship between antipsychotic receptor binding profiles and side-effects. Progress in Neuropsychopharmacology \& Biological Psychiatry 2018; Elsevier Inc, 84: 272-281. doi: 10.1016/j. pnpbp.2018.01.023.

35. Potkin SG, Keator DB, Kesler-West ML Nguyen DD, van Erp TG, Mukherjee J. (2014) 'D2 receptor occupancy following lurasidone treatment in patients with schizophrenia or schizoaffective disorder. CNS Spectrums 2014; 19:176-181. Doi: 10.1017/S109285291300059X.

36. Preskorn S, Ereshefsky L, Chiu YY, Poola N, Loebel A. Effect of food on the pharmacokinetics of lurasidone: results of two randomized, open-label, crossover studies †', Hum Psychopharmacol Clin Exp 2013, 28: 495-505. Doi: 10.1002/hup.

37. Roth BL, Sheffler DJ, Kroeze WK. Magic shotguns versus magic bullets: selectively non-selective drugs for mood disorders and schizophrenia. Nat Rev Drug Discov 2004; 3(4): 353-9.

38. Siwek M. Interakcje nowych leków przeciwpsychotycznych. W: Nowe leki przeciwpsychotyczne (red. Siwek M), Medical Education, Warszawa 2020, s. 245-255.

39. Solmi M, Murru A, Pacchiarotti I, Undurraga J, Veronese N, Fornaro $M$ et al. Safety, tolerability, and risks associated with first- and second- generation antipsychotics : a stateof-the-art clinical review. Therapeutics and Clinical Risk Management 2017; 13: 757-777. Sunovion Pharmaceuticals Inc. Latuda (Lurasidone hydrochloride) package insert. Marlborough (MA): Sunovion Pharmaceuticals Inc; 2013.

40. Spina E, Hiemke C and De Leon J. Assessing drug-drug interactions through therapeutic drug monitoring when administering oral second-generation antipsychotics. Expert Opinion on Drug Metabolism and Toxicology 2016; 12 (4): 407-422.

41. Sutton SC, Nause R, Gandelman K. The impact of gastric pH, volume, and emptying on the food effect of ziprasidone oral absorption'. The AAPS Journal 2017. Doi: 10.1208/s12248017-0065-9.

42. Takekita Y, Fabbri C, Kato M, Koshikawa Y, Tajika A, Kinoshita $\mathrm{T}$ et al. HTR1A polymorphisms and clinical efficacy of antipsychotic drug treatment in schizophrenia: A meta-analysis. International Journal of Neuropsychopharmacology 2015; 19 (5).Tian Y, Zalesky A, Bousman Ch, Pantelis C, Everall I. Insula functional connectivity in schizophrenia: Subregions, gradients and symptoms. Biological Psychiatry: Cognitive Neuroscience and Neuroimaging. Society of Biological Psychiatry 2019. doi: 10.1016/j.bpsc.2018.12.003.

43. Tyler MW, Zaldivar-Diez J, Haggarty SJ. Classics in Chemical Neuroscience: Haloperidol. ACS Chemical Neurosciene 2017; 8: 444-453. Doi: 10.1021/acschemneuro.7b00018.

44. Wasik, A., Krupa, A., and Siwek, M., 2019. Interactions of antidepressants, mood-stabilisers and antipsychotics with food. Pharmacotherapy in Psychiatry and Neurology, 35 (1), 51-74.

45. Wishart DS, Feunang YD, Guo AC, Lo EJ, Marcu A, Grant JR, et al. DrugBank 5.0: a major update to the DrugBank database for 2018. Nucleic Acids Res 2017 Nov 8. doi: 10.1093/ nar/gkx1037.

46. Wolke SA, Mehta MA, O'Daly Zelaya OF, Zahreddine N, Keren $\mathrm{H}$ et al. Modulation of anterior cingulate cortex reward and penalty signalling in medication-naive youngadult subjects with depressive symptoms following acute dose lurasidone. Psychological Medicine 2019; 49: 1365-1377.

47. Wong DF et al. Determination of dopamine D 2 receptor occupancy by lurasidone using positron emission tomography in healthy male subjects. Psychopharmacology 2013; 229(2): 245-52. doi: 10.1007/s00213-013-3103-z.

48. Woroń J, Siwek M, Wasik A. Interakcje leków w psychiatrii. Gdańsk 2019, AsteriaMed.

49. Woroń J, Siwek M. O interakcjach i powikłaniach farmakoterapii. W: Psychiatria w medycynie. T. 3: Dialogi interdyscyplinarne. Rymaszewska, J., Dudek, D. (red.). Warszawa, 2018, Medical Education, 203-227.

50. Wylie KP and Tregellas JR. The Role of the Insula in Schizophrenia. Schizophr Res 2010; 123(2-3): 93-104. Doi: 10.1016/j. schres.2010.08.027.

51. Yoshikawa A, Li J and Meltzer HY. A functional HTR1A polymorphism, rs6295, predicts short-term response to lurasidone : confirmation with meta-analysis of other antipsychotic drugs. The Pharmacogenomics Journal 2019. Springer US. Doi: 10.1038/s41397-019-0101-5. 